\title{
1 NADPH as a quality footprinting in horticultural crops marketability
}

2 Morteza Soleimani Aghdam ${ }^{1}$, José M. Palma ${ }^{2}$, Francisco J. Corpas ${ }^{2}$

$3{ }^{1}$ Department of Horticultural Science, Imam Khomeini International University, Qazvin, Iran.

$4 \quad$ E-mail address, soleimaniaghdam@eng.ikiu.ac.ir

$5{ }^{2}$ Department of Biochemistry, Cell and Molecular Biology of Plants, Group of Antioxidants,

6 Free Radicals and Nitric Oxide in Biotechnology, Food and Agriculture, Estación

7 Experimental del Zaidín, CSIC, C/Profesor Albareda, 1, 18008 Granada, Spain. E-mail

$8 \quad$ address, josemanuel.palma@eez.csic.es

9 *Corresponding author e-mail: soleimaniaghdam@eng.ikiu.ac.ir (Aghdam, M.S)

$10 *$ Corresponding author e-mail: javier.corpas@eez.csic.es (Corpas, F.J) 
Trends in Food Science \& Technology (accepted July, 2020)

12

Abstract

Background: During their post-harvest life, horticultural crops are affected by a diverse range of processes, such as natural in planta senescence and fungal infection, as well as artificial conservation techniques, leading to a deterioration in nutritional quality due to chilling damage. Given its intracellular reducing power, the supply of NADPH needs to be optimized in order to maintain multiple metabolic pathways involved in the natural ripening and post-harvest life of horticultural crops.

Scope and approach: As a whole series of reactions are involved in the generation and functioning of the cellular NADPH pool, the homeostasis of NADPH integrates and coordinates different metabolic pathways involved in physiological processes. In this review, we describe the major pathways in NADPH metabolism which modulate the principal enzymes present in subcellular compartments that generate and consume NADPH. Special attention will be paid to its role in fruits and vegetables and its possible use as an indicator of horticultural crop quality. In addition to playing a key role in cellular redox status, NADPH could also be used as a footprint of horticultural crop quality for marketing purposes given its involvement in processes such as photosynthesis, carbohydrate activity, reactive oxygen species (ROS) and fatty acid metabolisms, the pentose phosphate pathway, jasmonic acid biosynthesis, as well as shikimate and phenylpropanoid pathways operating in secondary metabolite biosynthesis.

Key findings and conclusions: Intracellular NADPH metabolism could provide a physiological, biochemical and molecular footprint for the sensory and nutritional quality of post-harvest horticultural crops and their marketing worldwide.

Keywords: Antioxidant systems, chilling injury, dehydrogenase, fungal decay, NADPH, ROS 
Trends in Food Science \& Technology (accepted July, 2020)

\section{Introduction}

Although the quality of fruits, vegetables and cut flowers is judged by consumers mainly on the basis of their external appearance, there is increasing awareness of the nutritional value, health properties and gastronomic potential of edible plants. In addition to taste, aroma and freshness, the presence of bioactive molecules such as vitamins, as well as antioxidants including ascorbate, vitamin E, carotenoids ( $\beta$-carotene and lycopene) and polyphenols (phenols, flavonoids and anthocyanins), is greatly valued by consumers. With their scavenging capacity, especially under abiotic and biotic stress conditions, many of these compounds, which provide endogenous protection against ROS (Habashi et al., 2019), play a vital role in a healthy human diet. Fruit and vegetable consumption reduces the risk of chronic diseases associated with oxidative stress-related diseases, such as cancer, obesity and cardiovascular pathologies, and age-related neurodegenerative diseases such as Alzheimer's and Parkinson's. This is particularly noteworthy in developed countries where life expectancy has risen considerably over a relatively short period of time (Kyriacou \& Rouphael, 2018). Thus, the sale of fleshy fruits and vegetables such as apples, apricots, blueberries, pomegranates, broccoli, cabbage, carrots, peppers and tomatoes, which contain higher levels of healthy phytochemicals, presents promising opportunities in the areas of health, biotechnology and economics (Bagetta et al., 2020).

Qualitative and quantitative deterioration in post-harvest horticultural crops causes major economic losses in the different phases of the horticultural industry including production, processing and shipping. To maintain post-harvest quality, low temperature storage is widely used to delay senescence in vegetables and ornamentals, as well as fruit ripening. However, this type of storage can result in damage such as fruit wounding and fungal decay (Aghdam et al., 2018; Wang, Mao, \& Ying, 2016). To ensure plant tolerance under these conditions, substantial efforts are being made to introduce safe ecofriendly strategies to delay senescence and to restore the sensory and nutritional properties of horticultural crops which are critical in the horticultural associated industry. There is a growing tendency worldwide to explore safe ecofriendly strategies, which would also cut economic losses, in order to enhance horticultural crop marketability.

The intracellular reducing power of reduced nicotinamide adenine dinucleotidephosphate (NADPH), a key indicator of optimal cellular redox status, is necessary in many metabolic pathways. The enzymatic cofactor NADPH also triggers or impedes the generation of reactive oxygen and nitrogen species (ROS/RNS) in subcellular compartments through different metabolic pathways. In addition, the antioxidant enzyme 
Trends in Food Science \& Technology (accepted July, 2020)

glutathione reductase (GR) in the plant ascorbate-glutathione pathway requires NADPH to order to regulate $\mathrm{H}_{2} \mathrm{O}_{2}$ levels in cytosols, chloroplasts, mitochondria and peroxisomes (Palma et al, 2015; Corpas et al., 2017) and for the detoxification of reactive carbonyls by various NADPH-dependent reductases (Yamauchi et al., 2011). NADPH is also essential for the membrane-bound superoxide $\left(\mathrm{O}_{2}{ }^{\circ}\right)$ generating NADPH oxidase (NOX) which is one of the main promoters for the formation $\mathrm{O}_{2}{ }^{-}$(Sagi, M.; Fluhr, 2006; Chu-Puga et al., 2019; González-Gordo et al., 2020) and facilitates the generation of nitric oxide (NO) by Larginine-dependent NO synthase-like activity (Corpas and Barroso, 2017; Kolbert et al., 2019). Similarly, NADPH is needed for the biosynthesis of jasmonic acid (JA) by 12oxophytodienoate reductase 3 (OPR3) isoenzyme, as well as secondary metabolism molecules such as terpenes, alkaloids, flavonoids and phytoalexins. Table 1 shows the principal enzymes that require NADPH to physiologically function in higher plants.

This review mainly aims to provide a comprehensive overview of the NADPH metabolism which could be a reliable footprint of post-harvest horticultural crop quality. We describe (i) the principal enzymatic components of NADPH metabolism in subcellular compartments; and (ii) how NADPH-generating enzymes function in horticultural crops under postharvest storage and conservation conditions such as chilling injury, fungal diseases and natural senescence. Finally, we describe the role of NADPH as a possible reliable biochemical marker of the sensory and nutritional quality of post-harvest horticultural crops worldwide for marketing purposes and increasing returns.

\section{Biochemical overview of NADPH homeostasis in plant cells.}

The optimal cellular NADPH pool requires the participation of different enzymatic systems either involved in the supply of the oxidized form $\left(\mathrm{NADP}^{+}\right)$as well as a family of dehydrogenases with the capacity to reduce it (Tables 1 and 2). All these systems, localized in subcellular compartments including cytosols, plastids, mitochondria and peroxisomes, act in coordination to maintain optimal redox status under different physiological and stress conditions. Figure 1 shows a model of these biochemical components involved in NADPH metabolism in different plant subcellular compartments. The supply of intracellular NADPH at the post-harvest stage could enhance the marketability of horticultural crops (Aghdam et al., 2019c, 2020; Li et al., 2020; Wei, et al., 2019). Accordingly, NADPH processes provide the metabolic signatures to attenuate stress conditions, delay senescence and to preserve the sensory and nutritional quality of post-harvest horticultural crops. 
Trends in Food Science \& Technology (accepted July, 2020)

\subsection{NAD kinase $(N A D K)$ as an $N A D P^{+}$supplying system}

Although cytosolic ATP-dependent NAD kinase (NADK) is, to our knowledge, the only enzyme that uses the phosphorylation of nicotinamide adenine dinucleotide $\left(\mathrm{NAD}^{+}\right)$to synthesize de novo $\mathrm{NADP}^{+}$(Tai et al., 2019), several NADK isoforms have been found to target peroxisomes and chloroplasts in the model Arabidopsis plant (Waller et al., 2009; Li et al., 2018; Corpas and Barroso, 2017).

In Arabidopsis, $\mathrm{NAD}^{+}$biosynthesis requires the supply of aspartate and the involvement of five enzymes, with L-aspartate oxidase, quinolinate synthetase and quinolinate phosphoribosyltransferase located in the chloroplast, while nicotinate mononucleotide adenylyltransferase and NAD synthetase are located in the cytosol, where the final biosynthesis steps take place (Hao et al., 2018). However, $\mathrm{NAD}^{+}$homeostasis in organelles is essential for cellular functionality which is maintained by several nicotinamide adenine dinucleotide (NAD) transporters (NDTs). Arabidopsis contains three transporters which belong to the mitochondrial carrier family. While NAD ${ }^{+}$carriers AtNDT1 (At2g47490) and AtNDT2 (At1g25380) target the inner mitochondrial membrane (Feitosa-Araujo et al., 2020), carrier AtPXN (At2g39970) is located in the peroxisomal membrane (de SouzaChaves et al., 2019). CaM/Ca ${ }^{2+}$-dependent NAD kinases have been reported to increase, via pathogen elicitors, the $\mathrm{NADP}^{+}$content necessary for oxidative burst (Gakière, et al., 2018; Gorelova et al., 2017b). Recently, $\mathrm{NAD}^{+}$metabolism has been demonstrated to be critical for tomato fruit ripening (Decros et al., 2019).

\subsection{Enzymatic systems with the capacity to generate NADPH}

Photosynthesis includes two important steps for NADP/NADPH: 1) the cytochrome b6/f complex, responsible for the proton electrochemical gradient (proton motive force) used for ATP biosynthesis by $\mathrm{CF}_{0} \mathrm{CF}_{1}$-ATPase and 2) ferredoxin $\mathrm{NADP}^{+}$reductase (FNR), responsible for NADPH biosynthesis via photosystem I. The supply of ATP and NADPH is crucial for $\mathrm{CO}_{2}$ fixation through the Calvin-Benson cycle (CBC) and to provide glyceraldehyde 3phosphate for starch biosynthesis by ADP-glucose pyrophosphorylase (AGPase) in the chloroplast and for sucrose biosynthesis by sucrose phosphate synthase (SPS) in the cytosol (Eva et al. 2019).

Alternative sources of NADPH are present in non-photosynthetic organs and the dark phase of photosynthesis. The oxidative pentose phosphate pathway (OxPPP) in cytosol, chloroplasts and peroxisomes supplies NADPH through the successive action of glucose-6phosphate dehydrogenase (G6PDH) and 6-phosphogluconate dehydrogenase (6PGDH) 
Trends in Food Science \& Technology (accepted July, 2020)

(Corpas et al., 1998; Millar, Whelan, Soole, \& Day, 2011) (Table 2). In addition, the OxPP pathway metabolically competes with the shikimate pathway which uses G6P in the first enzymatic step. The latter pathway also uses NADH and ATP which are generated in the glycolytic steps involving glyceraldehyde 3-phosphate and phosphoenolpyruvate, respectively (Millar, et al., 2011; Li et al., 2016).

In the chloroplast, ferredoxin-thioredoxin reductase (FTR) and NADPH-thioredoxin reductase (NTR) supply thioredoxins $f$ and $m$ to boost CBC activity under light conditions, accompanied by a restricted OxPP pathway which, in turn, boosts sucrose accumulation. However, during the night (dark phase), the supply of NADPH by the oxPP pathway enables NTR to maintain thioredoxin $f$ and $m$ function in the chloroplast despite limited CBC activity (Meyer et al. 2012). Also, during darkness, due to the supply of NADPH by the oxPP pathway, NTR enables thioredoxins $f, m, x, y$ and $z$ to function. This enhances the regulation of metabolic processes which include: (i) the electron transport system via the $\mathrm{CF}_{0} \mathrm{CF}_{1}$-ATPase complex; (ii) the malate valve through the NADP-malic enzyme (NADP$\mathrm{ME}$ ); (iii) transport of NADH and NADPH reducing power between chloroplasts, cytosol, mitochondria and peroxisomes; (iv) involvement of peroxiredoxins (Prxs) and methionine sulfoxide reductases (MSRs) in the ROS scavenging system; (v) starch biosynthesis by ADP-glucose pyrophosphorylase; (vi) fatty acid biosynthesis by acetyl-CoA carboxylase activity; (vii) chlorophyll biosynthesis by $\mathrm{Mg}^{2+}$ chelatase, $\mathrm{Mg}^{2+}$-protoporphyrin methyltransferase and glutamyl-transfer RNA reductase enzymes; (viii) chlorophyll degradation due to pheophorbide $a$ oxygenase; (ix) the shikimate pathway; and (x) the xanthophyll, or glutamine synthetase/glutamate synthase (GS/GOGAT), cycle containing the enzymes zeaxanthine epoxidase, glutamine synthetase and glutamine oxoglutarate aminotransferase (Geigenberger et al., 2017).

In non-photosynthetic plastids and cytosol, the other two sources of NADPH in addition to the OxPP pathway are NADP-dependent isocitrate dehydrogenase (NADP-ICDH) and the NADP malic enzyme (NADP-ME). NADP-ICDH, also present in mitochondria and peroxisomes, catalyzes the oxidative decarboxylation of isocitrate to 2-oxoglutarate, with the concomitant generation of NADPH (Table 2). The 2-oxoglutarate dehydrogenase enables NADP-ICDH to connect to the GS/GOGAT system, key enzymes involved in nitrogen assimilation (Hodges, Flesch, Gálvez, \& Bismuth, 2003; Corpas \& Barroso, 2014). NADP$\mathrm{ME}$ is engaged in the oxidative decarboxylation of malate to $\mathrm{CO}_{2}$, pyruvate and NADPH (Chen et al., 2019). In the bundle sheath chloroplasts of C4 plant crops, NADP-ME-generated 
Trends in Food Science \& Technology (accepted July, 2020)

$171 \mathrm{CO}_{2}$ is used by the $\mathrm{CBC}$ enzyme ribulose-1,5-bisphosphate carboxylase/oxygenase (RuBisCo) to enhance carbon fixation and thus crop productivity (Rao and Dixon, 2016).

In the cytosol, G6PDH and 6PGDH play a key role in supplying NADPH for thioredoxin $h$ under light conditions, which regulates the acetyl-CoA necessary for fatty acid biosynthesis and the phenylpropanoid pathway via the ATP citrate lyase and malate dehydrogenase $(\mathrm{MDH})$, a dehydrogenase in the malate valve involved in transporting the cellular reducing power of NADH and NADPH (Geigenberger, et al., 2017). This pumping mechanism facilitates the export of potential excess NADPH in the chloroplast which is converted into $\mathrm{NAD}^{+}$in the cytosol, thus maintaining intracellular redox homeostasis (Selinski \& Scheibe, 2019). Chloroplast NAD- and NADP-dependent MDHs produce malate from oxaloacetate accompanied by the malate/oxaloacetate shuttle which imports the oxaloacetate required into the chloroplast, with a concomitant export of malate to the cytosol.

Under light conditions, chloroplast FTR enhances $\mathrm{NADP}^{+}$-dependent $\mathrm{MDH}$ function in the light malate valve as part of a ROS avoidance strategy in response to high light stress. This facilitates the transport of NADPH from the chloroplast and thus prevents an excessive reduction in the electron transport system by NADPH accumulation (Selinski \& Scheibe, 2019).

In mitochondria, NTR provides thioredoxin (Trx) $h$ by upregulating the alternative oxidase (AOX) pathway (Del-Saz, et al., 2018; Geigenberger, et al., 2017). Under stress conditions, plant mitochondria have higher levels of citrate, which boosts NADPH production through NADP-ICDH and triggers $\operatorname{Tr} x h$ gene expression via NTR activity (Del-Saz, et al., 2018; Geigenberger, et al., 2017). Trx $o$ facilitates the regulation of the electron transport system by NADH dehydrogenase (NDH), succinate dehydrogenase (SDH), cytochrome $c$ oxidase (CCO) and ATP synthase $\left(\mathrm{F}_{0} \mathrm{~F}_{1}\right.$-ATPase). NADPH also plays a vital role in (i) alternative oxidase (AOX), uncoupling protein (UCP) and proton electrochemical gradient energy-dissipating pathways; (ii) photorespiratory glycine decarboxylase and serine hydroxymethyl transferase enzymes; (iii) GABA shunt pathways; (iv) glutamate biosynthesis by GS activity; (v) chaperone heat shock protein (HSP) accumulation and (vi) ROSscavenging mitochondrial Prx and MSR enzymes (Li et al., 2018; Wang et al., 2017). Mitochondrial methylenetetrahydrofolate dehydrogenase (MTHFDH) also supplies NADPH through the production of 10-formyl-THF from 5,10-methylene-THF (Gorelova et al. 2017a, 2017b).

Table 2 shows a summary of the catalyzed reactions, cellular processes and locations of the principal NADPH-generating enzymes in higher plants. 
Trends in Food Science \& Technology (accepted July, 2020)

\subsection{NADPH pyrophosphohydrolase, NUDX19}

Nudix hydrolases (NUDXs) are present in all organisms and have the capacity to hydrolase a wide range of organic pyrophosphates. Arabidopsis contains 28 NUDX genes (Yoshimura and Shigeoka, 2015), including NUDX19, which is present in plastids and peroxisomes and uses an NADPH recycling mechanism to hydrolase NADPH (Maruta et al. 2016). The NADP-ICDH, G6PDH, 6PGDH and NADP-ME activity in knock-out AtNUDX19 mutants is higher in the roots and leaves of Arabidopsis than in those of wild-type plants. These activities are even higher under arsenic oxidative stress conditions (Corpas et al., 2016), suggesting that a clear connection exists between these enzymes to maintain the NADPH pool, especially under stress conditions, although, to our knowledge, little is known about NUDX19 in horticultural crops.

\section{Intracellular NADPH as a quality footprinting in horticultural crops marketability}

As mentioned above, relatively little is known about NADPH metabolism in horticultural crops. Table 3 provides a summary of certain horticultural crops and the involvement of NADP-dehydrogenases (NADPH-DHs) in mechanisms of response to factors such as chilling stress, cold storage, senescence and fungal pathogens. Table 4 shows examples of increases in NADPH content caused by exogenous applications of different compounds that either reduce damage or provide resistance to pathogens.

\subsection{Chilling injury tolerance}

Although low temperatures are widely used to store fruits and vegetables, horticultural crops are susceptible to chilling injury (Liu et al., 2016; Palma et al., 2019). At the cellular level, intracellular ATP supply can be affected by damage to the mitochondrial inner membrane which reduces membrane selective permeability and increases electrolyte leakage. ROS accumulation increases in response to chilling stress due to NDH and CCR electrolyte leakage caused by increased lipid peroxidation of unsaturated membrane fatty acids (FAs) as indicated by higher malondialdehyde (MDA) levels. This is explained by the increase in phospholipase D (PLD) and lipoxygenase (LOX) activity involved in FA metabolism (Aghdam, et al. 2018).

Electrolyte leakage and MDA accumulation are widely used as membrane integrity markers (Aghdam et al., 2018). A sufficient supply of intracellular ATP and NADPH for FA biosynthesis, elongation and unsaturation impedes membrane damage caused by PLD and LOX and strengthens intracellular ROS-scavenging systems which confer chilling tolerance 
Trends in Food Science \& Technology (accepted July, 2020)

by preserving membrane integrity (Aghdam, et al., 2018). Recently, Morales and MunnéBosch (2019) reported that $\mathrm{H}_{2} \mathrm{O}_{2}$ and $\mathrm{ABA}$ accumulation in response to stress triggers an increase in aldehyde dehydrogenase activity and gene expression in order to maintain MDA levels, thus acting as signaling molecules in addition to supplying NADPH to improve horticultural crop marketability.

Early low temperature storage at $15^{\circ} \mathrm{C}$ for 2 days, followed by storage at $4{ }^{\circ} \mathrm{C}$ for 14 days, has been shown to attenuate chilling injury in zucchini (Cucurbita pepo L.) (Carvajal et al., 2015). Molecular and biochemical analyses showed an increase in G6PDH and NADP$M E$ gene expression, accompanied by an overall rise in the activity of antioxidant enzymes such as catalase (CAT), as well as all enzymatic components in the ascorbate-glutathione cycle including ascorbate peroxidase (APX), glutathione reductase (GR), dehydroascorbate reductase (DHAR) and monodehydroascorbate reductase (MDAR). This increase reduced $\mathrm{H}_{2} \mathrm{O}_{2}$ content while increasing ascorbate and proline accumulation, as well as $A O X$ gene expression. The exogenous application of nitric oxide (NO) confers chilling tolerance in banana fruits stored at $7{ }^{\circ} \mathrm{C}$ for 20 days (Wang, et al 2015). An increase in glucokinase and hexokinase activity was found to provide sufficient G6P for G6PDH and 6PGDH activity, accompanied by increased $\mathrm{H}^{+}$-ATPase, $\mathrm{Ca}^{2+}$-ATPase, shikimate dehydrogenase (SDH) and CCO enzymatic activity. This provided a sufficient supply of intracellular ATP, thus maintaining membrane integrity while electrolyte leakage declined.

In peach (Prunus persica L.) fruits, the exogenous application of melatonin reduces chilling injury. This raises G6PDH activity and erythrose 4-phosphate content, which triggers the shikimate pathway, as indicated by the increase in SDH activity, which provides NADPH and phenylalanine. Melatonin stimulates the phenylpropanoid pathway, accompanied by an increase in phenylalanine ammonia lease (PAL) activity, which triggers a rise in endogenous salicylic acid (SA) and phenol accumulation. In addition, palmitic (C16:0), stearic (C18:0) and oleic (C18:1) acid content was found to decline, while linoleic (C18:2) and linolenic (C18:3) acid accumulation rose (Gao, et al. 2018). On the other hand, exogenous applications of melatonin in Anthurium cut flowers stored at $4{ }^{\circ} \mathrm{C}$ for 21 days have been shown to attenuate chilling injury, as indicated by spathe browning (Aghdam, et al 2019a). This positive effect appears to be due to an accumulation of $\mathrm{H}_{2} \mathrm{O}_{2}$ caused by increased NADPH oxidase activity, accompanied by both higher $A O X$ gene expression and an increase in the activity of antioxidant enzymes including SOD, APX, CAT and GR. Proline accumulation was also observed due to increased ornithine aminotransferase (OAT) and pyrroline 5-carboxylate synthetase (P5CS) activity, along with lower PDH activity (Liu, et al., 
Trends in Food Science \& Technology (accepted July, 2020)

2016). In addition, phenol content and DPPH scavenging capacity rose as a result of enhanced PAL/polyphenol oxidase (PPO) activity and higher ascorbate/dehydroascorbate and GSH/GSSG ratios.

Similarly, exogenous treatment of tomato (Solanum lycopersicum L.) fruits with phenylalanine attenuated chilling damage during storage at $4{ }^{\circ} \mathrm{C}$ for 28 days, while NADPH content increased due to higher levels of mitochondrial methylenetetrahydrofolate dehydrogenase activity (Aghdam, et al. 2019c). This was accompanied by an increase in enzymatic and non-enzymatic antioxidant systems including SOD, CAT, APX, GR, ascorbate, lycopene, phenols and anthocyanins.

In summary, conferring chilling tolerance in post-harvest horticultural crops provides sufficient intracellular NADPH to stimulate biochemical mechanisms such as (i) ROS-generating NADPH oxidase and SOD/glutathione-ascorbate scavenging cycles; (ii) GABA shunt pathways; (iii) intracellular ATP supply; (iv) shikimate and phenylpropanoid pathways; (v) endogenous proline and SA accumulation; and (vi) FA membrane unsaturation and enrichment. All these mechanisms prevent membrane damage which is characterized by a reduction in electrolyte leakage and MDA levels.

\subsection{Involvement of NADPH in fungal decay tolerance}

Post-harvest fruits and vegetables are affected by fungal diseases which generate significant economic losses. To solve this problem, various strategies have been used, including the exogenous application of chemical fungicides and natural compounds such as melatonin, NO and polyamines, which involve the use of NADPH in many cases.

During fungal infection of horticultural crops, superoxide $\left(\mathrm{O}_{2}{ }^{--}\right)$-generating NADPH oxidase activity (Table 1) is indirectly responsible for subsequent $\mathrm{H}_{2} \mathrm{O}_{2}$ accumulation, with the dual benefit of cell wall fortification (Xiong et al. 2015) and direct defense against pathogens. $\mathrm{H}_{2} \mathrm{O}_{2}$ activity is crucial for cytosolic $\mathrm{Ca}^{2+}$ accumulation, which gives rise to endogenous SA concentrations in the cytoplasm by triggering isochorismate synthase (ICS) and PAL gene expression. In the cytoplasm, endogenous SA accumulation reduces the oligomeric protein encoded by the non-expresser of pathogenesis-related gene 1 (NPRI) to a monomer through the action of thioredoxin $h$. SA accumulation also facilitates the nuclear translocation of the NPR1 monomer from the cytoplasm in order to confer systemic acquired resistance (SAR) by triggering pathogenesis-related (PR) protein gene expression (Gao, Zhu, Kachroo, \& Kachroo, 2015; Meyer, et al., 2012; Tripathi, Raikhy, \& Kumar, 2019). 
Trends in Food Science \& Technology (accepted July, 2020)

On the other hand, the exogenous application of $\mathrm{NO}$ has been found to attenuate brown root decay in peach (Prunus persica) fruits during storage at $20^{\circ} \mathrm{C}$ for 4 days. NO triggers an increase in NADPH oxidase activity, followed by an increase in $\mathrm{O}_{2}{ }^{--}$and $\mathrm{H}_{2} \mathrm{O}_{2}$ content, with a concomitant accumulation of cytosolic $\mathrm{Ca}^{2+}$ and a boost in endogenous NO, SA and jasmonic acid (JA) levels (Shi, et al. 2015). In other cases, treatment with the fungicide acibenzolar-S-methyl (ASM) mitigated pink rot decay in muskmelon (Cucumis melo) fruit by boosting NADPH oxidase activity. The increased generation of $\mathrm{O}_{2}{ }^{--}$and $\mathrm{H}_{2} \mathrm{O}_{2}$ was accompanied by an increase in enzymatic and non-enzymatic antioxidants including SOD, APX, ascorbate and GSH (Ge, et al. 2015).

Treatment of apple fruits with ASM was observed to confer tolerance to blue mold decay caused by Penicillium espansum during storage at $24{ }^{\circ} \mathrm{C}$ for 12 days. The treatment increased G6PDH activity, followed by an increase in NADPH oxidase activity, while SOD and CAT activity decreased, resulting in an accumulation of $\mathrm{H}_{2} \mathrm{O}_{2}$, which is crucial for reducing fungal decay. Also, some studies have reported an increase in the gene expression and activity of ascorbate-glutathione cycle enzymes APX, GR, MDAR and DHAR, as well as in ascorbate and GSH content (Wei, et al. 2019; Li, et al. 2020).

Similarly, exogenous treatment of tomato fruits with melatonin attenuated gray mold decay (Li, et al. 2019b). A similar pattern, characterized by higher NADPH oxidase activity, followed by a rise in $\mathrm{O}_{2}^{--}$and $\mathrm{H}_{2} \mathrm{O}_{2}$, endogenous melatonin and SA accumulation, was observed. This triggered an increase in $\beta$-1,3-glucanase activity and the phenylpropanoid pathway, as indicated by increased PAL and coumarate CoA ligase (4CL) activity, as well as phenol and flavonoid content.

Li et al. (2019d) have reported that the exogenous application of spermidine and spermine diminishes black spot decay in apricot fruits during storage at $25^{\circ} \mathrm{C}$ for 10 days. These two polyamines triggered a cascade of responses, with an increase in NADPH oxidase, $\mathrm{O}_{2}{ }^{--}, \mathrm{H}_{2} \mathrm{O}_{2}$, SOD, CAT, APX, GR, ascorbate and GSH activity being observed. Wang et al. (2019) have shown that, during storage at $20^{\circ} \mathrm{C}$ for 5 days, exogenous treatment of grape berry fruits with $\beta$-aminobutyric acid (BABA), an isomer of $\gamma$ - aminobutyric acid (GABA), confers tolerance to gray mold decay caused by Botrytis cinerea. This non-proteinogenic amino acid triggers an increase in G6PDH and 6PGDH activity, with a concomitant increase in NADPH and the ascorbate-glutathione cycle. This was accompanied by higher ascorbate and GSH levels which boosted the translocation of NPR1 from cytosol to nucleus. NPRI genes then increased SAR by boosting SA and NO activity, as well as chitinase and $\beta$-1,3glucanase gene expression (Wang et al., 2019). 
Trends in Food Science \& Technology (accepted July, 2020)

In another case, exogenous applications of ATP attenuated postharvest decay caused by Lasiodiplodia theobromae and Phomopsis longanae, with less pericarp browning being observed in longan (Dimocarpus longan L.) fruits (Zhang, et al. 2017; Lin, et al. 2017a, 2018a). Increased NAD kinase activity was reported, leading to higher $\mathrm{NADP}^{+}$content, followed by an increase in OxPP pathway and antioxidant system activity. Similar responses were observed following treatment with SA (Chen, et al. 2020).

\subsection{NADPH homeostasis and senescence}

Significant efforts have made to delay fruit ripening and senescence, which adversely affect both quality and plant defenses, and to maintain the quality and nutritional properties of fruits. For example, exogenous treatment of longan fruits with antioxidant propyl gallate delays senescence symptoms during post-harvest storage at $15{ }^{\circ} \mathrm{C}$ for 10 days, with an increase observed in NAD kinase, $\mathrm{NADP}^{+}$and OxPP pathway activity. At the same time, both $\mathrm{NAD}^{+}$ and NADH content decreased, resulting in reduced glycolysis pathway, tricarboxylic acid cycle and mitochondrial cytochrome c oxidase activity, together with a decline in electrolyte leakage and MDA content. Meanwhile, antioxidant system activity increased, leading to a reduction in saturated FA content, with a concomitant increase in unsaturated FAs, including oleic, linoleic and linolenic acids. All these changes occurred alongside a reduction in polyphenol oxidase activity (Lin et al., 2013; Lin et al., 2018b; Lin et al., 2017b; Lin et al., 2015).

Chlorine dioxide $\left(\mathrm{ClO}_{2}\right)$ fumigation, which is used to delay post-harvest senescence in longan fruits, reduced pericarp browning and ensured a sufficient supply of NADPH from G6PDH and 6PGDH activity. This was accompanied by an increase in the enzymatic and non-enzymatic components of the ascorbate-glutathione cycle, thus preventing $\mathrm{H}_{2} \mathrm{O}_{2}$ accumulation (Chumyam et al. 2016). In addition to pericarp browning, post-harvest senescence can also lead to aril breakdown in longan fruits due to insufficient $\mathrm{NADP}^{+}$and reduced NAD kinase activity, thus limiting NADPH supply, as well as G6PDH and 6PGDH activity (Lin, et al. 2019a, 2019b, 2020).

$\mathrm{Li}$, et al. (2016) have reported that senescence in broccoli florets during storage at 10 ${ }^{\circ} \mathrm{C}$ for 32 days under specific atmospheric conditions $\left(50 \% \mathrm{CO}_{2} / 50 \% \mathrm{O}_{2}\right)$ was delayed by higher OxPP pathway and tricarboxylic acid cycle activity, as indicated by an increase in SDH levels. This occurred in conjunction with increased mitochondrial electron transport, leading to a rise in CCO activity and sufficient intracellular ATP and NADPH provision. Exogenous treatment with hydrogen sulfide $\left(\mathrm{H}_{2} \mathrm{~S}\right)$ also delayed senescence, as evidenced by 
Trends in Food Science \& Technology (accepted July, 2020) yellowing in broccoli florets caused by increased OxPP pathway, $\mathrm{H}^{+}$-ATPase, $\mathrm{Ca}^{2+}$-ATPase, $\mathrm{SDH}$ and $\mathrm{CCO}$ activity. Enhanced endogenous $\mathrm{H}_{2} \mathrm{~S}$ content, following increased biosynthesis of enzymes such as L-cysteine desulfhydrase (LCD) and D-cysteine desulfhydrase (DCD), maintained chlorophyll stability during post-harvest storage at $20^{\circ} \mathrm{C}$ for 3 days ( $\mathrm{Li}$ et al. 2017).

Similar responses were noted following treatment with methyl jasmonate of Agaricus bisporus mushrooms, which delays senescence by boosting OxPP pathway activity (Yang et al 2019b). The use of nanocomposites in the pressure composition packaging of golden needle mushrooms (Flammulina velutipes) during storage at $4{ }^{\circ} \mathrm{C}$ for 15 days also increased NAD kinase and G6PDH activity, as well as $\mathrm{NADP}^{+}$content. This was accompanied by lower mitochondrial activity but increased levels of SOD and catalase activity, as well as endogenous NO content (Donglu, et al., 2016; Yang, et al. 2019a; Shi, et al., 2020). However, other methods, such as storage at $2{ }^{\circ} \mathrm{C}$ for 24 days under specific atmospheric conditions (20 $\% \mathrm{CO}_{2} / 80 \% \mathrm{O}_{2}$ ) to enhance OxPPP and tricarboxylic acid cycle activity, can prevent senescence in mushrooms ( $\mathrm{Li}$ et al. 2019c).

Zhang et al. (2019) have reported that treatment of peach fruits with $\mathrm{H}_{2} \mathrm{~S}$ scavenger hypotaurine removes symptoms of senescence such as mesocarp and browning during storage at $0{ }^{\circ} \mathrm{C}$ for 60 days. Hypotaurine increases NADPH oxidase gene expression and activity, with a concomitant rise in antioxidant SOD and CAT enzyme activity, as well as ascorbate and phenolic compounds. Simultaneous treatment of longan fruits with $\mathrm{SO}_{2}$ and $\mathrm{Cl}_{2} \mathrm{O}$ during storage at $25{ }^{\circ} \mathrm{C}$ for 8 days reduces pericarp browning, apparently due to increased NADPH oxidase and SOD gene expression and activity, thus facilitating fine-tuned regulation of $\mathrm{H}_{2} \mathrm{O}_{2}$ content (Joradol et al. 2019). Interestingly, treatment with $\mathrm{H}_{2} \mathrm{O}_{2}$ has been reported to reduce browning in fresh-cut guava fruits stored at $25{ }^{\circ} \mathrm{C}$ for 2 days by boosting OxPP pathway activity. This provided sufficient NADPH to trigger an increase in NTR and Prx activity and ascorbate content, as well as a reduction in electrolyte leakage and MDA content (Chumyam et al. 2019).

The application of other high molecular weight compounds such as chitosan in nectarine fruit stored at $25{ }^{\circ} \mathrm{C}$ for 8 days also delays postharvest senescence. Under these conditions, OxPPP activity was found to increase intracellular NADPH concentrations, enzymatic and non-enzymatic antioxidants, as well as phenol and flavonoid content (Zhang, et al. (2019)

Other studies have shown that chemicals such as benzo-(1,2,3)-thiadiazole-7carbothioic, S-methyl ester (BTH) and salicylic (SA) acids trigger SAR in the absence of a 
Trends in Food Science \& Technology (accepted July, 2020)

406

407

408

409

410

411

412

413

414

415

416

417

418

419

420

421

422

423

424

425

426

427

428

429

430

431

432

433

434

435

436

437

pathogen (Anfoka, 2000). Thus, treatment with BTH of potato tubers stored at $20{ }^{\circ} \mathrm{C}$ for 3 days aided wound healing (Jiang, et al. 2020). BTH triggered an increase in NADPH oxidase, polyamine oxidase (PAO), cell wall peroxidase (CWP), as well as SOD, CAT, APX and GR gene expression and activity.

Delaying the senescence of horticultural crops through post-harvest treatments provides the intracellular NADPH required to initiate a cascade of metabolic responses which affect elements such as ROS metabolism, NADPH oxidase and antioxidant systems, NO and $\mathrm{H}_{2} \mathrm{~S}$ content, ATP levels and fatty acid unsaturated-enriched membranes. All these responses maintain membrane integrity by reducing electrolyte leakage and MDA accumulation and by stimulating enzymes involved in shikimate and phenylpropanoid pathways which are sources of secondary metabolites such as flavonoids, coumarins and lignans. Overall, all data indicated above provide evidences of the relevant role played by NADPH to maintain the fruit and vegetable stability after a series of damage-promoting events.

\subsection{NADPH and mechanism to preserve nutritional quality}

The use of methods, such as the treatment of fruits and vegetables with ROS-scavenging phytochemicals, to maintain the nutritional quality of horticultural crops is on the rise given the growing interest of consumers in this human health issue (Kyriacou \& Rouphael, 2018). In these crops, NADPH plays a critical role in providing phenylalanine required by shikimate and phenylpropanoid pathways for the accumulation of phenols, flavonoids and anthocyanins (Aghdam et al., 2018; Ge, et al., 2019).

Adyanthaya et al. (2009) have reported that the supply of NADPH through increased G6PDH activity counters the deterioration in apple fruit quality during cold storage by boosting proline biosynthesis. This ensures a sufficient supply of ATP by proline dehydrogenase and P5C dehydrogenase activity and enhances ROS-scavenging system and phenylpropanoid pathway activity for phenol accumulation, in addition to DPPH-scavenging capacity. The authors found that the OxPP and proline biosynthesis pathways need to be synchronized with $\mathrm{FADH}_{2}, \mathrm{NADH}$ and glutamate production in order to supply the intracellular ATP, NADPH and carbon skeletons necessary for shikimate and phenylpropanoid pathways and to inhibit ROS accumulation. Xu et al. (2014) have reported that blue light boosts anthocyanin accumulation in strawberry fruits stored at $5^{\circ} \mathrm{C}$ for 12 days, together with an increase in G6PDH activity. This provides vital NADPH and phenylalanine for the shikimate and phenylpropanoid pathways, respectively. 
Trends in Food Science \& Technology (accepted July, 2020)

The exogenous application of ATP attenuated post-harvest mushroom cap browning by increasing NADPH oxidase and shikimate pathway activity, which supplies the amino acid tryptophan and boosts endogenous melatonin accumulation. Meanwhile, the phenylpropanoid pathway triggered phenolic compound accumulation (Aghdam et al 2019b).

Li et al. (2019a) have shown that an increase in invertase activity in response to exogenous applications of sucrose, leading to an increased supply of glucose and fructose, has a positive effect on strawberry fruits stored at $20^{\circ} \mathrm{C}$ for 4 days by enhancing anthocyanin accumulation, as well as OxPP and shikimate pathway activity. Recently, Aghdam et al. (2020) reported higher levels of G6PDH and 6PGDH activity in response to treatment with melatonin, which maintained the nutritional quality of pomegranate fruits stored at $4{ }^{\circ} \mathrm{C}$ for 120 days. The effect of the treatment on the phenylpropanoid pathway led to an accumulation of phenolic and anthocyanin compounds and stimulated antioxidant systems. On the other hand, hot air and UV-C treatment enhanced anthocyanin accumulation in peach fruit stored at $1{ }^{\circ} \mathrm{C}$ for 35 days due to increased G6PDH gene expression and activity and activated the phenylpropanoid pathway (Zhou et al. 2020).

\section{NADPH homeostasis during fruit ripening}

Studies have demostrated the involvement of NADPH in the ripening process of fruits. Kong et al. (2007) have indicated that an increase in both plastid and cytosolic G6PDH activity in peach fruits during ripening boosts flavonoid and anthocyanin accumulation through the supply of NADPH and erythritol 4-phosphate for the shikimate and phenylpropanoid pathways. Adequate provision of NADPH is essential for shikimate dehydrogenase activity in the shikimate pathway and for flavone synthase, dihydroflavonol 4reductase, anthocyanidin reductase and leucoanthocyanidin reductase activity in the phenylpropanoid pathway (Francini, Giro, \& Ferrante, 2019).

A progressive reduction in endogenous NO content, associated with an increase in S-nitrosation and tyrosine nitration proteins, was observed during sweet pepper (Capsicum annuum L.) fruit ripening (Rodríguez-Ruiz et al., 2017; Palma et al. 2019). In addition, the exogenous application of NO gas was found to delay pepper fruit ripening by reversing nitrosothiol and nitroprotein accumulation (Chaki, et al., 2015) and to lower catalase activity due to tyrosine nitration and S-nitrosation (Chaki et al 2015; Rodríguez-Ruiz et al., 2019; Palma et al., 2020), leading to an increase in ROS accumulation and lipid peroxidation. On the other hand, the increase observed in lipid peroxidation led to higher levels of NADPH 
Trends in Food Science \& Technology (accepted July, 2020)

oxidase activity during pepper fruit ripening and to differential modulation of the seven isozymes involved in NADPH oxidase activity (Chu-Puga et al. 2019; González-Gordo et al., 2020). A reduction in NO and GSH content, in addition to APX activity during pepper fruit ripening, was accompanied by an increase in proline content. During the ripening process, $\mathrm{O}_{2}{ }^{--}$production rose due to NADPH oxidase activity, which indirectly generated peroxynitrite by reacting with NO. This gave rise to physiological nitrooxidative stress (Chu-Puga, et al., 2019), with catalase observed to be the main target for tyrosine nitration. NADPdehydrogeasnes also behaved differentially during pepper ripening, with a decrease in G6PDH and NADP-ICDH activity and a significant increase observed in 6PGDH and NADP-ME activity. However, both NADP-ICDH and NADP-ME were negatively modulated by both nitration and persulfidation, a $\mathrm{H}_{2} \mathrm{~S}$-mediated postranslational modification (Muñoz-Vargas, et al. 2018, 2020). Furthermore, the exogenous application of NO was found to delay pepper fruit ripening and to trigger a significant rise (40\%) in vitamin $\mathrm{C}$ due to increased mitochondrial L-galactono-1,4-lactone dehydrogenase (GalLDH) activity and gene expression, which catalyzed the last step in ascorbate biosynthesis (Rodríguez-Ruiz et al., 2017). Exogenous treatment of pepper fruit with NO gas is therefore an excellent example of the potential of certain compounds to delay ripening in post-harvest horticultural crops and to add nutritional value by increasing vitamin $\mathrm{C}$ content.

\section{Conclusion}

Fruit and vegetable horticulture industry involves breeding, pollination, germination, early and late growth and development, flowering, fruit setting and ripening, harvesting, postharvest activity, marketing, distribution and ultimately sale to the consumer. Its principal aim is to produce attractive, highly nutritious fruits and vegetables that are uniform in ripening, size, shape and freshness. This is attained by metabolic optimization at the cellular and organ level in numerous biochemical pathways that require NADPH homeostasis and the involvement of all subcellular organelles. Given that redox cellular status reflects the generation and use of NADPH content, this review provides a comprehensive overview of NADPH metabolism in crop plants, the enzymes involved in generating this coenzyme and its role as a marker of horticultural crop quality and marketability. Enzymatic systems that generate and consume NADPH protect against external post-harvest crop storage conditions such as chilling damage and fungal decay. Figure 2 shows a simple model of the principal NADPH homeostatic systems which affect the physiological development and ripening of fruits and vegetables, as well as mechanisms of protection against adverse post-harvest 
Trends in Food Science \& Technology (accepted July, 2020)

storage conditions. Under these conditions, NADPH-generating enzymes such as G6PDH and 6PGDH, in addition to $\mathrm{NADPH}$-consuming systems including $\mathrm{O}_{2}{ }^{--}$-generating $\mathrm{NADPH}$ oxidase and ascorbate-glutathione cycle components, are also involved in the ROS metabolism. All these processes affect plant redox homeostasis, which, together with $\mathrm{NADPH}$, play key roles as markers of horticultural crop quality and marketability.

Conflict of interest Authors declare that they have no conflict of interest.

\section{Acknowledgements}

FJC and JMP research is supported by a European Regional Development Fund cofinanced grant from the Spanish Ministry of Economy and Competitiveness (PID2019-103924GB-I00), the Plan Andaluz de Investigación, Desarrollo e Innovación (PAIDI 2020) (P18-FR-1359) and Junta de Andalucía (group BIO192), Spain.

\section{References}

Adyanthaya, I., Kwon, Y. I., Apostolidis, E., \& Shetty, K. (2009). Apple postharvest preservation is linked to phenolic content and superoxide dismutase activity. Journal of food biochemistry, 33, 535-556.

Aghdam, M. S., Jannatizadeh, A., Luo, Z., \& Paliyath, G. (2018). Ensuring sufficient intracellular ATP supplying and friendly extracellular ATP signaling attenuates stresses, delays senescence and maintains quality in horticultural crops during postharvest life. Trends in Food Science \& Technology, 76, 67-81.

Aghdam, M. S., Jannatizadeh, A., Nojadeh, M. S., \& Ebrahimzadeh, A. (2019). Exogenous melatonin ameliorates chilling injury in cut anthurium flowers during low temperature storage. Postharvest Biology and Technology, 148, 184-191.

Aghdam, M. S., Kakavand, F., Rabiei, V., Zaare-Nahandi, F., \& Razavi, F. (2019). $\gamma$ Aminobutyric acid and nitric oxide treatments preserve sensory and nutritional quality of cornelian cherry fruits during postharvest cold storage by delaying softening and enhancing phenols accumulation. Scientia Horticulturae, 246, 812-817.

Aghdam, M. S., Luo, Z., Jannatizadeh, A., \& Farmani, B. (2019). Exogenous adenosine triphosphate application retards cap browning in Agaricus bisporus during low temperature storage. Food Chemistry, 293, 285-290.

Aghdam, M. S., Luo, Z., Jannatizadeh, A., Sheikh-Assadi, M., Sharafi, Y., Farmani, B., Fard, J. R., \& Razavi, F. (2019). Employing exogenous melatonin applying confers chilling tolerance in tomato fruits by upregulating ZAT2/6/12 giving rise to promoting endogenous polyamines, proline, and nitric oxide accumulation by triggering arginine pathway activity. Food Chemistry, 275, 549-556.

Aghdam, M. S., Luo, Z., Li, L., Jannatizadeh, A., Fard, J. R., \& Pirzad, F. (2020). Melatonin treatment maintains nutraceutical properties of pomegranate fruits during cold storage. Food Chemistry, 303, 125385.

Aghdam, M. S., Moradi, M., Razavi, F., \& Rabiei, V. (2019). Exogenous phenylalanine application promotes chilling tolerance in tomato fruits during cold storage by ensuring supply of NADPH for activation of ROS scavenging systems. Scientia Horticulturae, 246, 818-825. 
Anfoka GH (2000) Benzo-(1,2,3)-thiadiazole-7-carbothioic acid S-methyl ester induces systemic resistance in tomato (Lycopersicon esculentum. Mill cv. Vollendung) to Cucumber mosaic virus. Crop Protection 19, 401-405

Bagetta, D., Maruca, A., Lupia, A., Mesiti, F., Catalano, R., Romeo, I., Moraca, F., Ambrosio, F. A., Costa, G., \& Artese, A. (2020). Mediterranean products as promising source of multi-target agents in the treatment of metabolic syndrome. European Journal of Medicinal Chemistry, 186, 111903.

Carvajal, F., Palma, F., Jamilena, M., \& Garrido, D. (2015). Preconditioning treatment induces chilling tolerance in zucchini fruit improving different physiological mechanisms against cold injury. Annals of Applied Biology, 166, 340-354.

Chaki, M., Alvarez de Morales, P., Ruiz, C., Begara-Morales, J. C., Barroso, J. B., Corpas, F. J., \& Palma, J. M. (2015). Ripening of pepper (Capsicum annuum) fruit is characterized by an enhancement of protein tyrosine nitration. Ann Bot, 116, 637-647.

Chen, Q., Wang, B., Ding, H., Zhang, J., \& Li, S. (2019). The role of NADP-malic enzyme in plants under stress. Plant Science, 281, 206-212.

Chen S, Wang L, Xia M, Wu D, Liao Y, Wang K, Zheng Y (2019) Effect of $\beta$-aminobutyric acid treatment on redox status and induction of disease resistance in postharvest peach fruits. Food Science, 40(1), 209-215.

Chen, Y., Sun, J., Lin, H., Lin, M., Lin, Y., Wang, H., \& Hung, Y.-C. (2020). Salicylic acid reduces the incidence of Phomopsis longanae Chi infection in harvested longan fruit by affecting the energy status and respiratory metabolism. Postharvest Biology and Technology, 160, 111035.

Chu-Puga, A., Gonzalez-Gordo, S., Rodriguez-Ruiz, M., Palma, J. M., \& Corpas, F. J. (2019). NADPH Oxidase (Rboh) Activity is Up Regulated during Sweet Pepper (Capsicum annuum L.) Fruit Ripening. Antioxidants (Basel), 8.

Chumyam, A., Faiyue, B., \& Saengnil, K. (2019). Reduction of enzymatic browning of freshcut guava fruit by exogenous hydrogen peroxide-activated peroxiredoxin/thioredoxin system. Scientia Horticulturae, 255, 260-268.

Chumyam, A., Shank, L., Uthaibutra, J., \& Saengnil, K. (2016). Effects of chlorine dioxide on mitochondrial energy levels and redox status of 'Daw' longan pericarp during storage. Postharvest Biology and Technology, 116, 26-35.

Corpas FJ, Aguayo-Trinidad S, Ogawa T, Yoshimura K, Shigeoka S. (2016) Activation of NADPH-recycling systems in leaves and roots of Arabidopsis thaliana under arsenicinduced stress conditions is accelerated by knock-out of Nudix hydrolase 19 (AtNUDX19) gene. J Plant Physiol. 192:81-9.

Corpas, F. J., \& Barroso, J. B. (2014). Functional implications of peroxisomal nitric oxide (NO) in plants. Front Plant Sci, 5, 97.

Corpas, F. J., \& Barroso, J. B. (2014). NADPH-generating dehydrogenases: their role in the mechanism of protection against nitro-oxidative stress induced by adverse environmental conditions. Frontiers in Environmental Science, 2.

Corpas, F. J., \& Barroso, J. B. (2017). Nitric oxide synthase-like activity in higher plants. Nitric oxide: biology and chemistry, 68, 5.

Corpas, F. J., Barroso, J. B., Palma, J. M., \& Rodriguez-Ruiz, M. (2017). Plant peroxisomes: A nitro-oxidative cocktail. Redox Biol, 11, 535-542.

Corpas, F. J., Barroso, J. B., Sandalio, L. M., Distefano, S., Palma, J. M., Lupiáñez, J. A., \& del Río, L. A. (1998). A dehydrogenase-mediated recycling system of NADPH in plant peroxisomes. The Biochemical journal, 330 ( Pt 2), 777-784.

de Souza Chaves, I., Feitosa-Araujo, E., Florian, A., Medeiros, D. B., da Fonseca-Pereira, P., Charton, L., Heyneke, E., Apfata, J. A., Pires, M. V., \& Mettler-Altmann, T. (2019). 
The mitochondrial NAD ${ }^{+}$transporter (NDT 1) plays important roles in cellular $\mathrm{NAD}^{+}$ homeostasis in Arabidopsis thaliana. The Plant Journal, 100, 487-504.

Decros, G., Beauvoit, B., Colombie, S., Cabasson, C., Bernillon, S., Arrivault, S., Guenther, M., Belouah, I., Prigent, S., Baldet, P., Gibon, Y., \& Petriacq, P. (2019). Regulation of pyridine nucleotide metabolism during tomato fruit development through transcript and protein profiling. Front Plant Sci, 10, 1201.

Del-Saz, N. F., Ribas-Carbo, M., McDonald, A. E., Lambers, H., Fernie, A. R., \& FlorezSarasa, I. (2018). An in vivo perspective of the role(s) of the alternative oxidase pathway. Trends Plant Sci, 23, 206-219.

Donglu, F., Wenjian, Y., Kimatu, B. M., Xinxin, A., Qiuhui, H., \& Liyan, Z. (2016). Effect of nanocomposite packaging on postharvest quality and reactive oxygen species metabolism of mushrooms (Flammulina velutipes). Postharvest Biology and Technology, 119, 49-57.

Eva, C., Oszvald, M., \& Tamas, L. (2019). Current and possible approaches for improving photosynthetic efficiency. Plant Sci, 280, 433-440.

Feitosa-Araujo, E., Chaves, I. d. S., Florian, A., da Fonseca-Pereira, P., Apfata, J. A. C., Heyneke, E., Medeiros, D. B., Pires, M. V., Mettler-Altmann, T., \& Neuhaus, H. E. (2020). Down-regulation of a Mitochondrial NAD ${ }^{+}$Transporter (NDT2) Alters Seed Production and Germination in Arabidopsis. Plant and Cell Physiology.

Francini, A., Giro, A., \& Ferrante, A. (2019). Biochemical and molecular regulation of phenylpropanoids pathway under abiotic stresses. In Plant Signaling Molecules (pp. 183-192): Elsevier.

Gakière, B., Hao, J., de Bont, L., Pétriacq, P., Nunes-Nesi, A., \& Fernie, A. R. (2018). NAD ${ }^{+}$ biosynthesis and signaling in plants. Critical Reviews in Plant Sciences, 37, 259-307.

Gao, H., Lu, Z., Yang, Y., Wang, D., Yang, T., Cao, M., \& Cao, W. (2018). Melatonin treatment reduces chilling injury in peach fruit through its regulation of membrane fatty acid contents and phenolic metabolism. Food Chemistry, 245, 659-666.

Gao, Q.-M., Zhu, S., Kachroo, P., \& Kachroo, A. (2015). Signal regulators of systemic acquired resistance. Frontiers in Plant Science, 6, 228.

Ge, Y., Chen, Y., Li, C., Zhao, J., Wei, M., Li, X., Yang, S., \& Mi, Y. (2019). Effect of sodium nitroprusside treatment on shikimate and phenylpropanoid pathways of apple fruit. Food Chemistry, 290, 263-269.

Ge, Y., Deng, H., Bi, Y., Li, C., Liu, Y., \& Dong, B. (2015). Postharvest ASM dipping and DPI pre-treatment regulated reactive oxygen species metabolism in muskmelon (Cucumis melo L.) fruit. Postharvest Biology and Technology, 99, 160-167.

Geigenberger, P., Thormahlen, I., Daloso, D. M., \& Fernie, A. R. (2017). The Unprecedented versatility of the plant thioredoxin system. Trends Plant Sci, 22, 249-262.

González-Gordo, S., Rodríguez-Ruiz, M., Palma, J. M., \& Corpas, F. J. (2020). Superoxide Radical Metabolism in Sweet Pepper (Capsicum annuum L.) Fruits is regulated by ripening and by a NO-enriched environment. Frontiers in Plant Science, 11, 485.

Gorelova, V., Ambach, L., Rebeille, F., Stove, C., \& Van Der Straeten, D. (2017). Folates in plants: research advances and progress in crop biofortification. Front Chem, 5, 21.

Gorelova, V., De Lepeleire, J., Van Daele, J., Pluim, D., Mei, C., Cuypers, A., Leroux, O., Rebeille, F., Schellens, J. H. M., Blancquaert, D., Stove, C. P., \& Van Der Straeten, D. (2017). Dihydrofolate reductase/thymidylate synthase fine-tunes the folate status and controls redox homeostasis in plants. Plant Cell, 29, 2831-2853.

Habashi, R., Hacham, Y., Dhakarey, R., Matityahu, I., Holland, D., Tian, L., \& Amir, R. (2019). Elucidating the role of shikimate dehydrogenase in controlling the production of anthocyanins and hydrolysable tannins in the outer peels of pomegranate. $B M C$ Plant Biol, 19, 476. 
Hao, J., Pétriacq, P., de Bont, L., Hodges, M., \& Gakière, B. (2018). Characterization of 1aspartate oxidase from Arabidopsis thaliana. Plant Science, 271, 133-142.

Hodges, M., Flesch, V., Gálvez, S., \& Bismuth, E. (2003). Higher plant NADP ${ }^{+}$-dependent isocitrate dehydrogenases, ammonium assimilation and NADPH production. Plant Physiology and Biochemistry, 41, 577-585.

Joradol, A., Uthaibutra, J., Lithanatudom, P., \& Saengnil, K. (2019). Induced expression of NOX and SOD by gaseous sulfur dioxide and chlorine dioxide enhances antioxidant capacity and maintains fruit quality of 'Daw' longan fruit during storage through $\mathrm{H}_{2} \mathrm{O}_{2}$ signaling. Postharvest Biology and Technology, 156.

Kolbert, Z., Barroso, J. B., Brouquisse, R., Corpas, F. J., Gupta, K. J., Lindermayr, C., Loake, G. J., Palma, J. M., Petřivalský, M., \& Wendehenne, D. (2019). A forty year journey: The generation and roles of NO in plants. Nitric Oxide.

Kong, W.-F., Chen, J.-Y., Hou, Z.-X., Wen, P.-F., Zhan, J.-C., Pan, Q.-H., \& Huang, W.-D. (2007). Activity and subcellular localization of glucose-6-phosphate dehydrogenase in peach fruits. Journal of Plant Physiology, 164, 934-944.

Kyriacou, M. C., \& Rouphael, Y. (2018). Towards a new definition of quality for fresh fruits and vegetables. Scientia Horticulturae, 234, 463-469.

Lee GY, Kim HM, Ma SH, Park SH, Joung YH, Yun CH. (2014) Heterologous expression and functional characterization of the NADPH-cytochrome P450 reductase from Capsicum annuum. Plant Physiol Biochem. 82:116-22.

Li, B.-B., Wang, X., Tai, L., Ma, T.-T., Shalmani, A., Liu, W.-T., Li, W.-Q., \& Chen, K.-M. (2018). NAD kinases: metabolic targets controlling redox co-enzymes and reducing power partitioning in plant stress and development. Frontiers in Plant Science, 9, 379.

Li, C., Wei, M., Ge, Y., Zhao, J., Chen, Y., Hou, J., Cheng, Y., Chen, J., \& Li, J. (2020). The role of glucose-6-phosphate dehydrogenase in reactive oxygen species metabolism in apple exocarp induced by acibenzolar-S-methyl. Food Chemistry, 308, 125663.

Li, D., Li, L., Ge, Z., Limwachiranon, J., Ban, Z., Yang, D., \& Luo, Z. (2017). Effects of hydrogen sulfide on yellowing and energy metabolism in broccoli. Postharvest Biology and Technology, 129, 136-142.

Li, D., Li, L., Xiao, G., Limwachiranon, J., Xu, Y., Lu, H., Yang, D., \& Luo, Z. (2018). Effects of elevated $\mathrm{CO}_{2}$ on energy metabolism and $\gamma$-aminobutyric acid shunt pathway in postharvest strawberry fruit. Food Chemistry, 265, 281-289.

Li, D., Limwachiranon, J., Li, L., Du, R., \& Luo, Z. (2016). Involvement of energy metabolism to chilling tolerance induced by hydrogen sulfide in cold-stored banana fruit. Food Chemistry, 208, 272-278.

Li, D., Zhang, X., Xu, Y., Li, L., Aghdam, M. S., \& Luo, Z. (2019). Effect of exogenous sucrose on anthocyanin synthesis in postharvest strawberry fruit. Food Chemistry, 289, 112-120.

Li, L., Lv, F.-y., Guo, Y.-y., \& Wang, Z.-q. (2016). Respiratory pathway metabolism and energy metabolism associated with senescence in postharvest Broccoli (Brassica oleracea L. var. italica) florets in response to $\mathrm{O}_{2} / \mathrm{CO}_{2}$ controlled atmospheres. Postharvest Biology and Technology, 111, 330-336.

Li, S., Xu, Y., Bi, Y., Zhang, B., Shen, S., Jiang, T., \& Zheng, X. (2019). Melatonin treatment inhibits gray mold and induces disease resistance in cherry tomato fruit during postharvest. Postharvest Biology and Technology, 157.

Li, Y., Ma, Y., Zhang, T., Bi, Y., Wang, Y., \& Prusky, D. (2019). Exogenous polyamines enhance resistance to Alternaria alternata by modulating redox homeostasis in apricot fruit. Food Chemistry, 301. 
Lin, L., Lin, Y., Lin, H., Lin, M., Ritenour, M. A., Chen, Y., Wang, H., Hung, Y.-C., \& Lin, Y. (2019). Comparison between 'Fuyan' and 'Dongbi' longans in aril breakdown and respiration metabolism. Postharvest Biology and Technology, 153, 176-182.

Lin, Y.-F., Hu, Y.-H., Lin, H.-T., Liu, X., Chen, Y.-H., Zhang, S., \& Chen, Q.-X. (2013). Inhibitory effects of propyl gallate on tyrosinase and its application in controlling pericarp browning of harvested longan fruits. Journal of Agricultural and Food Chemistry, 61, 2889-2895.

Lin, Y., Chen, M., Lin, H., Hung, Y. C., Lin, Y., Chen, Y., Wang, H., \& Shi, J. (2017). DNP and ATP induced alteration in disease development of Phomopsis longanae Chiinoculated longan fruit by acting on energy status and reactive oxygen species production-scavenging system. Food Chem, 228, 497-505.

Lin, Y., Lin, H., Chen, Y., Wang, H., Lin, M., Ritenour, M. A., \& Lin, Y. (2020). The role of ROS-induced change of respiratory metabolism in pulp breakdown development of longan fruit during storage. Food Chemistry, 305, 125439.

Lin, Y., Lin, Y., Lin, H., Chen, Y., Wang, H., \& Shi, J. (2018). Application of propyl gallate alleviates pericarp browning in harvested longan fruit by modulating metabolisms of respiration and energy. Food Chem, 240, 863-869.

Lin, Y., Lin, Y., Lin, H., Shi, J., Chen, Y., \& Wang, H. (2017). Inhibitory effects of propyl gallate on membrane lipids metabolism and its relation to increasing storability of harvested longan fruit. Food Chem, 217, 133-138.

Lin, Y., Lin, Y., Lin, H., Zhang, S., Chen, Y., \& Shi, J. (2015). Inhibitory effects of propyl gallate on browning and its relationship to active oxygen metabolism in pericarp of harvested longan fruit. LWT - Food Science and Technology, 60, 1122-1128.

Liu, Z., Li, L., Luo, Z., Zeng, F., Jiang, L., \& Tang, K. (2016). Effect of brassinolide on energy status and proline metabolism in postharvest bamboo shoot during chilling stress. Postharvest Biology and Technology, 111, 240-246.

Maruta T, Ogawa T, Tsujimura M, Ikemoto K, Yoshida T, Takahashi H, Yoshimura K, Shigeoka S. (2016) Loss-of-function of an Arabidopsis NADPH pyrophosphohydrolase, AtNUDX19, impacts on the pyridine nucleotides status and confers photooxidative stress tolerance. Sci Rep. 6:37432.

Meyer, Y., Belin, C., Delorme-Hinoux, V., Reichheld, J. P., \& Riondet, C. (2012). Thioredoxin and glutaredoxin systems in plants: molecular mechanisms, crosstalks, and functional significance. Antioxid Redox Signal, 17, 1124-1160.

Millar, A. H., Whelan, J., Soole, K. L., \& Day, D. A. (2011). Organization and regulation of mitochondrial respiration in plants. Annual review of plant biology, 62, 79-104.

Morales, M., \& Munne-Bosch, S. (2019). Malondialdehyde: Facts and Artifacts. Plant Physiol, 180, 1246-1250.

Muñoz-Vargas, M. A., González-Gordo, S., Canas, A., López-Jaramillo, J., Palma, J. M., \& Corpas, F. J. (2018). Endogenous hydrogen sulfide $\left(\mathrm{H}_{2} \mathrm{~S}\right)$ is up-regulated during sweet pepper (Capsicum annuum L.) fruit ripening. In vitro analysis shows that NADPdependent isocitrate dehydrogenase (ICDH) activity is inhibited by $\mathrm{H} 2 \mathrm{~S}$ and NO. Nitric Oxide, 81, 36-45.

Muñoz-Vargas, M. A., González-Gordo, S., Palma, J. M., \& Corpas, F. J. (2020). Inhibition of NADP-malic enzyme activity by $\mathrm{H}_{2} \mathrm{~S}$ and NO in sweet pepper (Capsicum annuum L.) fruits. Physiol Plant. 168(2), 278-288.

Palma, J. M., Freschi, L., Rodríguez-Ruiz, M., González-Gordo, S., \& Corpas, F. J. (2019). Nitric oxide in the physiology and quality of fleshy fruits. J Exp Bot. 70(17), 44054417. 
Palma JM, Mateos RM, López-Jaramillo J, Rodríguez-RuiZ M, González-Gordo S, LechugaSancho M, Corpas FJ (2020) Plant catalases as NO and $\mathrm{H}_{2} \mathrm{~S}$ targets. Redox Biol 34:101525.

Palma, J. M., Sevilla, F., Jimenez, A., del Rio, L. A., Corpas, F. J., Álvarez de Morales, P., \& Camejo, D. M. (2015). Physiology of pepper fruit and the metabolism of antioxidants: chloroplasts, mitochondria and peroxisomes. Ann Bot, 116, 627-636.

Rao, X., \& Dixon, R. A. (2016). The differences between NAD-ME and NADP-ME subtypes of $\mathrm{C} 4$ photosynthesis: more than decarboxylating enzymes. Frontiers in Plant Science, 7,1525 .

Sagi, M., \& Fluhr, R. (2006). Production of reactive oxygen species by plant NADPH oxidases. Plant Physiology, 141, 336-340.

Selinski, J., \& Scheibe, R. (2019). Malate valves: old shuttles with new perspectives. Plant Biol (Stuttg), 21 Suppl 1, 21-30.

Shi, C., Wu, Y., Fang, D., Ma, N., Mariga, A. M., Hu, Q., \& Yang, W. (2020). Nanocomposite packaging regulates extracellular ATP and programed cell death in edible mushroom (Flammulina velutipes). Food Chem, 309, 125702.

Shi, J. Y., Liu, N., Gu, R. X., Zhu, L. Q., Zhang, C., Wang, Q. G., Lei, Z. H., Liu, Y. Y., \& Ren, J. Y. (2015). Signals induced by exogenous nitric oxide and their role in controlling brown rot disease caused by Monilinia fructicola in postharvest peach fruit. Journal of General Plant Pathology, 81, 68-76.

Tai, L., Li, B.-B., Nie, X.-M., Zhang, P.-P., Hu, C.-H., Zhang, L., Liu, W.-T., Li, W.-Q., \& Chen, K.-M. (2019). Calmodulin is the fundamental regulator of NADK-mediated NAD signaling in plants. Frontiers in Plant Science, 10.

Tripathi, D., Raikhy, G., \& Kumar, D. (2019). Chemical elicitors of systemic acquired resistance-Salicylic acid and its functional analogs. Current Plant Biology, 17, 4859.

Waller, J. C., Dhanoa, P. K., Schumann, U., Mullen, R. T., \& Snedden, W. A. (2010). Subcellular and tissue localization of NAD kinases from Arabidopsis: compartmentalization of de novo NADP biosynthesis. Planta, 231, 305.

Wang, D., Li, L., Xu, Y., Limwachiranon, J., Li, D., Ban, Z., \& Luo, Z. (2017). Effect of Exogenous Nitro Oxide on chilling tolerance, polyamine, proline, and $\gamma$-aminobutyric acid in bamboo shoots (Phyllostachys praecox f. prevernalis). J Agric Food Chem, 65, 5607-5613.

Wang, K., Wu, D., Bo, Z., Chen, S., Wang, Z., Zheng, Y., \& Fang, Y. (2019). Regulation of redox status contributes to priming defense against Botrytis cinerea in grape berries treated with $\beta$-aminobutyric acid. Scientia Horticulturae, 244, 352-364.

Wang, Y., Luo, Z., Huang, X., Yang, K., Gao, S., \& Du, R. (2014). Effect of exogenous $\gamma$ aminobutyric acid (GABA) treatment on chilling injury and antioxidant capacity in banana peel. Scientia Horticulturae, 168, 132-137.

Wang, Y., Luo, Z., Khan, Z. U., Mao, L., \& Ying, T. (2015). Effect of nitric oxide on energy metabolism in postharvest banana fruit in response to chilling stress. Postharvest Biology and Technology, 108, 21-27.

Wang, Y., Luo, Z., Mao, L., \& Ying, T. (2016). Contribution of polyamines metabolism and GABA shunt to chilling tolerance induced by nitric oxide in cold-stored banana fruit. Food Chemistry, 197, 333-339.

Wei, M., Ge, Y., Li, C., Han, X., Qin, S., Chen, Y., Tang, Q., \& Li, J. (2019). G6PDH regulated NADPH production and reactive oxygen species metabolism to enhance disease resistance against blue mold in apple fruit by acibenzolar-S-methyl. Postharvest Biology and Technology, 148, 228-235. 
Xiong, J., Yang, Y., Fu, G., \& Tao, L. (2015). Novel roles of hydrogen peroxide (H2O2) in regulating pectin synthesis and demethylesterification in the cell wall of rice (Oryza sativa) root tips. New Phytologist, 206, 118-126.

Xu, F., Cao, S., Shi, L., Chen, W., Su, X., \& Yang, Z. (2014). Blue light irradiation affects anthocyanin content and enzyme activities involved in postharvest strawberry fruit. $J$ Agric Food Chem, 62, 4778-4783.

Yamauchi, Y., Hasegawa, A., Taninaka, A., Mizutani, M., \& Sugimoto, Y. (2011). NADPHdependent reductases involved in the detoxification of reactive carbonyls in plants. Journal of Biological Chemistry, 286, 6999-7009.

Yang, W., Shi, C., Hu, Q., Wu, Y., Fang, D., Pei, F., \& Mariga, A. M. (2019). Nanocomposite packaging regulate respiration and energy metabolism in Flammulina velutipes. Postharvest Biology and Technology, 151, 119-126.

Yang, W., Wu, Y., Hu, Q., Mariga, A. M., \& Pei, F. (2019). Ultrahigh-pressure liquid chromatography-quadrupole-time-of-flight mass spectrometry-based metabolomics reveal the mechanism of methyl jasmonate in delaying the deterioration of Agaricus bisporus. Journal of Agricultural and Food Chemistry, 67, 8773-8782.

Yoshimura K, Shigeoka S. (2015) Versatile physiological functions of the Nudix hydrolase family in Arabidopsis. Biosci Biotechnol Biochem. 79(3):354-66.

Zhang, S., Lin, H., Lin, Y., Lin, Y., Hung, Y. C., Chen, Y., Wang, H., \& Shi, J. (2017). Energy status regulates disease development and respiratory metabolism of Lasiodiplodia theobromae (Pat.) Griff. \& Maubl.-infected longan fruit. Food Chem, 231, 238-246.

Zhang, S., Lin, Y., Lin, H., Lin, Y., Chen, Y., Wang, H., Shi, J., \& Lin, Y. (2018). Lasiodiplodia theobromae (Pat.) Griff. \& Maubl.-induced disease development and pericarp browning of harvested longan fruit in association with membrane lipids metabolism. Food Chem, 244, 93-101.

Zhang, W., Zhao, H., Zhang, J., Sheng, Z., Cao, J., \& Jiang, W. (2019). Different molecular weights chitosan coatings delay the senescence of postharvest nectarine fruit in relation to changes of redox state and respiratory pathway metabolism. Food Chem, 289, 160-168.

Zhang, Y., Gong, Y., Chen, L., Peng, Y., Wang, Q., \& Shi, J. (2019). Hypotaurine delays senescence of peach fruit by regulating reactive oxygen species metabolism. Scientia Horticulturae, 253, 295-302.

Zhou, D., Li, R., Zhang, H., Chen, S., \& Tu, K. (2020). Hot air and UV-C treatments promote anthocyanin accumulation in peach fruit through their regulations of sugars and organic acids. Food Chemistry, 309, 125726.

Zhu Y, Li HJ, Su Q, Wen J, Wang Y, Song W, Xie Y, He W, Yang Z, Jiang K, Guo H. (2019) A phenotype-directed chemical screen identifies ponalrestat as an inhibitor of the plant flavin monooxygenase YUCCA in auxin biosynthesis. J Biol Chem. 294(52):1992319933 


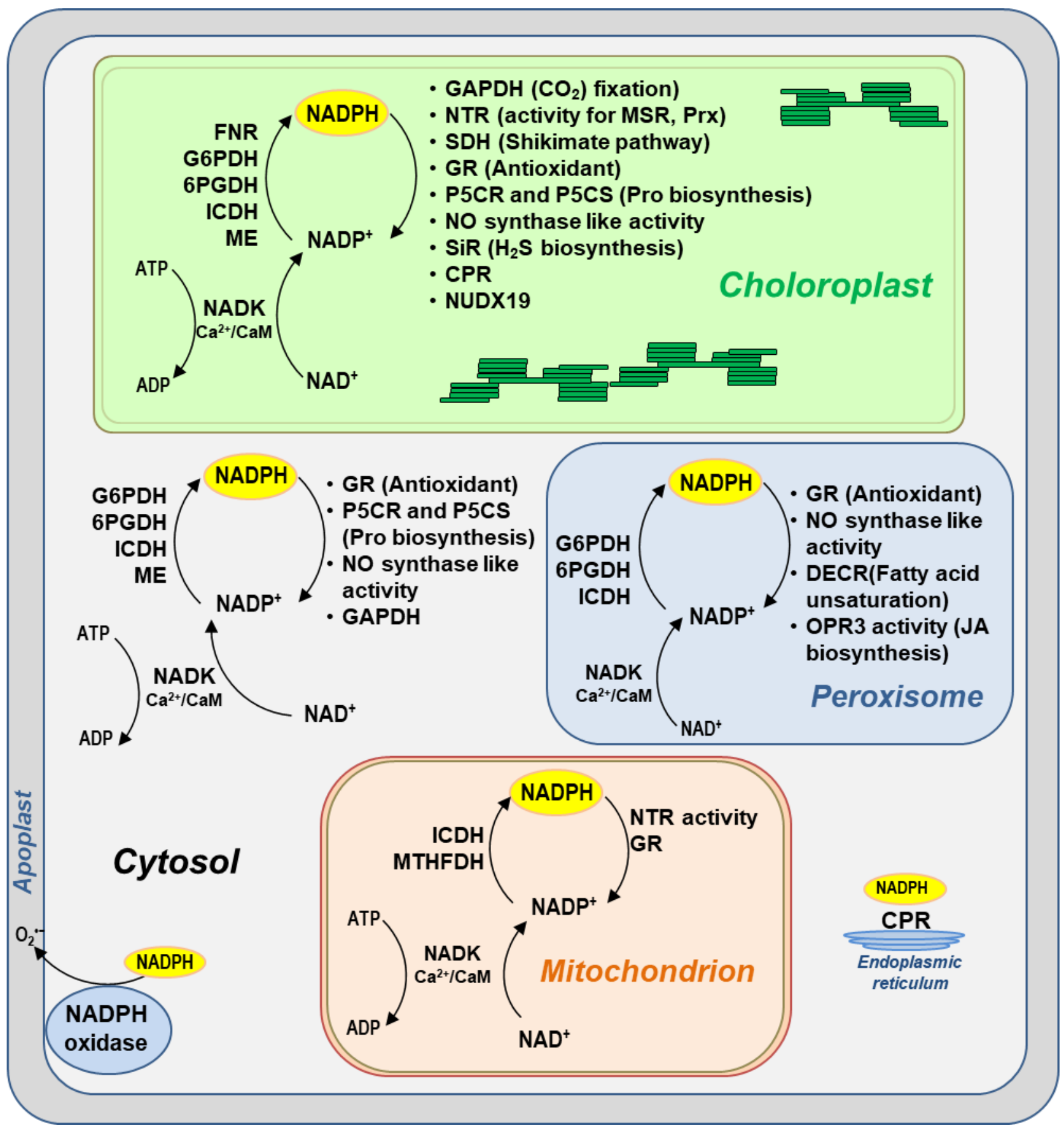

Figure 1. NADPH metabolism in the main subcellular compartments of plant cells. CPR, NADPH-cytochrome P450 oxidoreductase. DECR, 2,4-dienoyl-CoA reductase. FNR, ferredoxin-NADP reductase. GAPDH, NADP- glyceraldehyde-3phosphate dehydrogenase. G6PDH, glucose-6-phosphate dehydrogenase. 6PGDH, 6-phosphogluconate dehydrogenase. GR, glutathione reductase. MTHFDH, methylenetetrahydrofolate dehydrogenase. NADK, NAD kinase. NADP-ICDH, NADP-dependent isocitrate dehydrogenase. NADP-ME, NADP-dependent malic enzyme. NTR, NADPH-dependent thioredoxin reductase. $\mathrm{O}_{2}{ }^{-}$, superoxide radical. P5CR, pyrroline-5-carboxylate reductase. P5CS, pyrroline-5-carboxylate synthase. $\mathrm{SDH}$, shikimate dehydrogenase. 


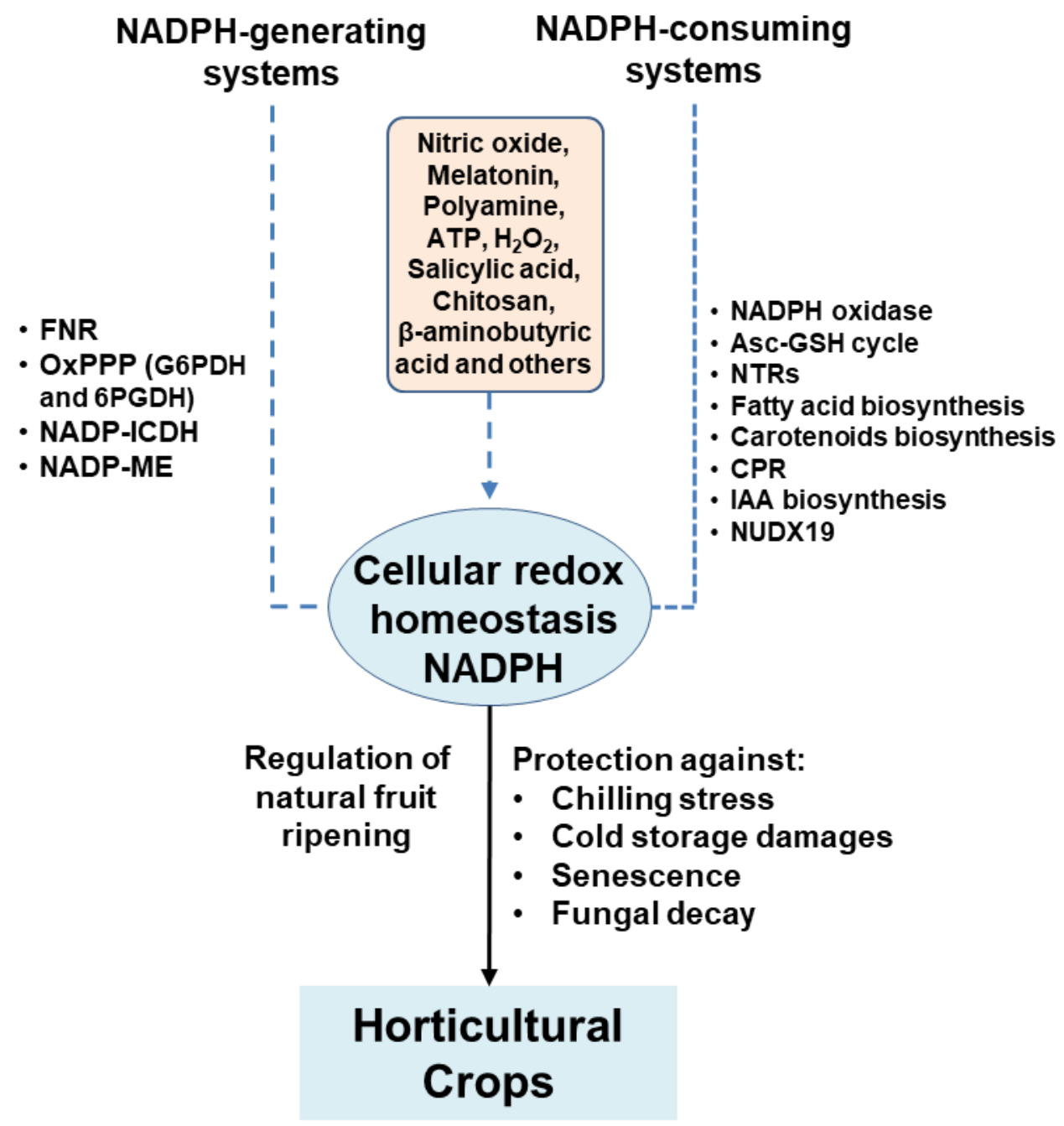

Figure 2. Hypothetical model of the relevance of the NADPH cellular redox homeostasis as a quality footprinting in horticultural crops under physiological process and under postharvest conditions. Exogenous compounds such as nitric oxide, melatonin, and others, seem to modulate the NADPH homeostasis providing beneficial effects on horticultural crops. Asc, ascorbate. CPR, NADPH-cytochrome P450 oxidoreductase. FNR, ferredoxinNADP reductase. G6PDH, glucose-6-phosphate dehydrogenase. 6PGDH, 6phosphogluconate dehydrogenase. GSH, glutathione. IAA, indole-3-acetic acid. NADP-ICDH, NADP-dependent isocitrate dehydrogenase. NADP-ME, NADPdependent malic enzyme. NTR, NADPH-dependent thioredoxin reductase. OxPPP, oxidative pentose phosphate pathway. NUDX19, Nudix hydrolase 19 
Trends in Food Science \& Technology (accepted July, 2020)

835 Table 1. Representative plant enzymes that require NADPH to perform their function

836

\begin{tabular}{|c|c|c|}
\hline $\begin{array}{l}\text { NADPH-dependent } \\
\text { enzyme }\end{array}$ & Biochemical pathway/ Function & Reference \\
\hline $\begin{array}{l}\text { NADPH oxidase (plant } \\
\text { respiratory burst oxidase } \\
\text { homolog, } \mathrm{RBOH})\end{array}$ & Superoxide anion $\left(\mathrm{O}_{2}{ }^{--}\right)$generation & Sagi and Fluhr, 2006 \\
\hline NO synthase-like activity & $\begin{array}{l}\text { NO generation / Signalling functions that } \\
\text { can mediate post-translational modifications } \\
\text { ( } S \text {-nitrosation and nitration). }\end{array}$ & $\begin{array}{l}\text { Barroso et al., 1999; Corpas } \\
\text { et al., } 2004\end{array}$ \\
\hline Glutathione reductase (GR) & $\begin{array}{l}\text { Ascorbate-glutathione pathway / Allows also } \\
\text { the regeneration of GSH which is one of the } \\
\text { most abundant antioxidants in plants }\end{array}$ & $\begin{array}{l}\text { Jiménez et al., } 1998 ; \\
\text { Romero-Puertas et al., } 2006\end{array}$ \\
\hline $\begin{array}{l}\text { NADPH-dependent } \\
\text { thioredoxin reductases (NTR) }\end{array}$ & Regulate chloroplast redox homeostasis & $\begin{array}{l}\text { Serrato et al., 2004; Cha et } \\
\text { al., } 2015\end{array}$ \\
\hline $\begin{array}{l}\text { 2,4-dienoyl-CoA reductase } \\
\text { (DECR) }\end{array}$ & $\begin{array}{l}\beta \text {-oxidation pathway / Participates } \\
\text { specifically it in the degradation of } \\
\text { unsaturated fatty acids }\end{array}$ & $\begin{array}{l}\text { Behrends et al., 1998; } \\
\text { Goepfert and Poirier, } 2007\end{array}$ \\
\hline $\begin{array}{l}\text { 12-oxophytodienoate } \\
\text { reductase (OPR3) }\end{array}$ & $\begin{array}{l}\text { Biosynthesis of jasmonic acid (JA) / } \\
\text { Involved in plant defense }\end{array}$ & Schaller et al., 2000 \\
\hline NADPH-dependent reductases & Detoxification of reactive carbonyls & Yamauchi et al., 2011 \\
\hline $\begin{array}{l}\text { NADPH-cytochrome P450 } \\
\text { oxidoreductase (CPR) }\end{array}$ & $\begin{array}{l}\text { Involved in the metabolism of terpenes, } \\
\text { alkaloids, flavonoids, and phytoalexins }\end{array}$ & $\begin{array}{l}\text { Canto-Canché and Loyola- } \\
\text { Vargas (2001); Ho et al. } \\
\text { 2002; Jensen and Møller, } \\
\text { 2010; Lee et al., 2014; Niu et } \\
\text { al., } 2017\end{array}$ \\
\hline $\begin{array}{l}\text { Nudix hydrolase } 19 \\
\text { (NUDX19) }\end{array}$ & Regulation of NADPH content & $\begin{array}{l}\text { Yoshimura and Shigeoka, } \\
\text { 2015; Maruta et al., } 2016\end{array}$ \\
\hline $\begin{array}{l}\text { YUCCA flavin-containing } \\
\text { monooxygenase }\end{array}$ & $\begin{array}{l}\text { Converts indole-3-pyruvate (IPA) to the } \\
\text { auxin indole-3-acetate (IAA) }\end{array}$ & $\begin{array}{l}\text { Zhao et al., 2001; Dai et al., } \\
\text { 2013; Zhu et al., } 2019\end{array}$ \\
\hline
\end{tabular}

837 
Trends in Food Science \& Technology (accepted July, 2020)

840 Table 2. Main NADPH-generating enzymes in higher plants indicating the catalyzed 841 enzymatic reaction, cellular/physiological process and its subcellular location

\begin{tabular}{|c|c|c|c|}
\hline $\begin{array}{l}\text { NADPH-generating dehydrogenases/ } \\
\text { Reaction }\end{array}$ & Cellular process & $\begin{array}{l}\text { Subcellular } \\
\text { location }\end{array}$ & Reference \\
\hline $\begin{array}{l}\text { Ferredoxin NADP } \text { Neductase }^{+} \text {re } \\
(\text { FNR, EC 1.18.1.2) } \\
\text { Reduced ferredoxin + NADP } \\
\rightarrow \text { oxidized ferredoxin + NADPH }\end{array}$ & Photosynthesis & Chloroplast & $\begin{array}{l}\text { Mulo and } \\
\text { Medina, } 2017\end{array}$ \\
\hline $\begin{array}{l}\text { Glucose 6-phosphate dehydrogenase } \\
\text { (G6PDH, EC 1.1.1.49) } \\
\text { D-glucose 6-phosphate + NADP } \rightarrow \text { 6- } \\
\text { phospho-D-glucono-1,5-lactone + NADPH }\end{array}$ & $\begin{array}{l}\text { Oxidative pentose } \\
\text { phosphate pathway } \\
\text { (OPPP) }\end{array}$ & $\begin{array}{l}\text { Cytosol } \\
\text { Chloroplast } \\
\text { Peroxisome }\end{array}$ & $\begin{array}{l}\text { von Schaewen et } \\
\text { al., } 1995 ; \text { Corpas } \\
\text { et al. } 1998\end{array}$ \\
\hline $\begin{array}{l}\text { 6-Phosphogluconate dehydrogenase } \\
\text { (6PGDH, EC 1.1.1.44) } \\
\text { 6-phosphogluconate + NADP } \rightarrow \text { ribulose } \\
\text { 5-phosphate }+\mathrm{CO}_{2}+\mathrm{NADPH}\end{array}$ & OPPP & $\begin{array}{l}\text { Cytosol } \\
\text { Chloroplast } \\
\text { Peroxisome }\end{array}$ & $\begin{array}{l}\text { Corpas et al. } \\
\text { 1998; Hölscher et } \\
\text { al., 2014, } 2016\end{array}$ \\
\hline $\begin{array}{l}\text { NADP isocitrate dehydrogenase (NADP- } \\
\text { ICDH, EC 1.1.1.42) } \\
\text { Isocitrate }+\mathrm{NADP} \rightarrow \\
\text { 2-oxoglutarate }+\mathrm{CO}_{2}+\mathrm{NADPH}\end{array}$ & $\begin{array}{l}\text { Ammonium } \\
\text { assimilation. Cycling, } \\
\text { redistribution } \\
\text { and export of amino } \\
\text { acids }\end{array}$ & $\begin{array}{l}\text { Cytosol } \\
\text { Chloroplast } \\
\text { Mitochondrion } \\
\text { Peroxisome }\end{array}$ & $\begin{array}{l}\text { Gálvez and } \\
\text { Gadal, 1995; } \\
\text { Corpas et al. } \\
1999 \\
\text { Leterrier et al. } \\
2016 \\
\end{array}$ \\
\hline $\begin{array}{l}\text { NADP-malic enzyme (NADP-ME, EC } \\
1.1 .1 .40) \\
\text { Malate }+\mathrm{NADP} \rightarrow \\
\text { pyruvate }+\mathrm{CO}_{2}+\mathrm{NADPH}\end{array}$ & $\begin{array}{l}\text { Malate/oxaloacetate } \\
\text { shuttle serving as } \\
\text { malate valve }\end{array}$ & $\begin{array}{c}\text { Cytosol } \\
\text { Chloroplast }\end{array}$ & $\begin{array}{l}\text { Drincovich et al., } \\
\text { 2001; } \\
\text { Mateos et al., } \\
\text { 2009; }\end{array}$ \\
\hline $\begin{array}{l}\text { NADP-glyceraldehyde-3-phosphate } \\
\text { dehydrogenase } \\
\text { (GAPDH, EC 1.2.1.9) } \\
\text { glyceraldehyde-3-phosphate + NADP } \rightarrow \\
\text { phosphoglycerate + NADPH }\end{array}$ & $\begin{array}{l}\text { Involved in the } \\
\text { photosynthetic } \\
\text { reductive pentose } \\
\text { phosphate pathway }\end{array}$ & $\begin{array}{c}\text { Cytosol } \\
\text { Chloroplast }\end{array}$ & $\begin{array}{l}\text { Gao and } \\
\text { Loescher, 2000; } \\
\text { WH. Petersen et } \\
\text { al (2003) }\end{array}$ \\
\hline $\begin{array}{l}\text { Shikimate dehydrogenase (SDH, EC } \\
1.1 .1 .25) \\
\text { shikimate + NADP } \rightarrow \text { 3-dehydroshikimate } \\
+ \text { NADPH }\end{array}$ & $\begin{array}{l}\text { Biosynthesis of } \\
\text { aromatic amino acids } \\
\text { (phenylalanine, } \\
\text { tyrosine, and } \\
\text { tryptophan) }\end{array}$ & Chloroplast & $\begin{array}{l}\text { Singh and } \\
\text { Christendat, } 2006 \\
\text { Habashi et al., } \\
2019\end{array}$ \\
\hline $\begin{array}{l}\text { Methylenetetrahydrofolate } \\
\text { dehydrogenase } \\
\text { (MTHFDH, EC 1.5.1.5) } \\
\text { 5,10-methylenetetrahydrofolate + NADP } \rightarrow \\
5,10 \text {-methenyltetrahydrofolate + NADPH }\end{array}$ & Folate pathway & Mitochondrion & $\begin{array}{l}\text { Groth et al., } \\
\text { 2016; Gorelova } \\
\text { et al., } 2017 b\end{array}$ \\
\hline
\end{tabular}


Trends in Food Science \& Technology (accepted July, 2020)

844 Table 3. Representative examples of horticultural crops where NADP-dehydrogenases are 845 involved in the mechanism of response against difference external damages. G6PDH, glucose846 6-phosphate dehydrogenase. 6PGDH, 6-phosphogluconate dehydrogenase. MTHFDH, 847 methylenetetrahydrofolate dehydrogenase. NADP-ME, NADP-dependent malic enzyme. SDH, 848 shikimate dehydrogenase.

\begin{tabular}{|c|c|c|c|}
\hline Horticultural crop & NADP-DHs & Main Effect & Reference \\
\hline \multicolumn{4}{|l|}{ Chilling stress } \\
\hline $\begin{array}{l}\text { Zucchini fruit } \\
\text { (Cucurbita pepo L.) }\end{array}$ & $\begin{array}{l}\text { Higher } G 6 P D H \text { and } N A D P- \\
M E \text { expression }\end{array}$ & $\begin{array}{l}\text { Attenuate chilling } \\
\text { injury }\end{array}$ & $\begin{array}{l}\text { Carvajal et al. } \\
(2015)\end{array}$ \\
\hline $\begin{array}{l}\text { Banana fruit } \\
\text { (Musa spp. Cavendish) }\end{array}$ & $\begin{array}{l}\text { Higher G6PDH and 6PGDH } \\
\text { activities }\end{array}$ & $\begin{array}{l}\text { Attenuate chilling } \\
\text { injury }\end{array}$ & Wang et al. (2015) \\
\hline $\begin{array}{l}\text { Peach fruit } \\
\text { (Prunus persica) }\end{array}$ & $\begin{array}{l}\text { Melatonin treatment triggers } \\
\text { higher G6PDH SDH } \\
\text { activities }\end{array}$ & $\begin{array}{l}\text { Attenuate chilling } \\
\text { injury }\end{array}$ & Gao et al., (2018) \\
\hline $\begin{array}{l}\text { Tomato fruit } \\
\text { (Solanum lycopersicum L.) }\end{array}$ & Higher MTHFD activity & $\begin{array}{l}\text { Attenuate chilling } \\
\text { injury }\end{array}$ & $\begin{array}{l}\text { Aghdam et al. } \\
(2019 \mathrm{c})\end{array}$ \\
\hline \multicolumn{4}{|l|}{ Cold storage } \\
\hline $\begin{array}{l}\text { Apple fruit } \\
\text { (Malus domestica L.) }\end{array}$ & Higher G6PDH activity & $\begin{array}{l}\text { Alleviate } \\
\text { deterioration }\end{array}$ & $\begin{array}{l}\text { Adyanthaya et al. } \\
(2009)\end{array}$ \\
\hline $\begin{array}{l}\text { Strawberry fruit } \\
\text { (Fragaria ananassa) }\end{array}$ & Higher G6PDH activity & \begin{tabular}{|l|} 
Improve \\
nutritional quality
\end{tabular} & $\begin{array}{l}\text { Xu, et al. (2014); } \\
\text { Li et al. (2019a) }\end{array}$ \\
\hline $\begin{array}{l}\text { Pomegranate fruit } \\
(\text { Punica granatum } \mathrm{L} .)\end{array}$ & $\begin{array}{l}\text { Higher G6PDH and 6PGDH } \\
\text { activities }\end{array}$ & $\begin{array}{l}\text { Improve } \\
\text { nutritional quality }\end{array}$ & $\begin{array}{l}\text { Aghdam et al. } \\
(2020)\end{array}$ \\
\hline $\begin{array}{l}\text { Peach fruit } \\
\text { (Prunus persica L.) }\end{array}$ & Higher G6PDH activity & \begin{tabular}{|l} 
Improve \\
nutritional quality
\end{tabular} & Zhou et al. (2020) \\
\hline \multicolumn{4}{|l|}{ Senescence } \\
\hline $\begin{array}{l}\text { Apple fruit } \\
\text { (Malus domestica L.) }\end{array}$ & NADP-malic enzyme & $\begin{array}{l}\text { Necessary to } \\
\text { delete senescence }\end{array}$ & Xi et al. (2016) \\
\hline $\begin{array}{l}\text { Longan fruit } \\
\text { (Dimocarpus longan L.) }\end{array}$ & $\begin{array}{l}\text { Higher G6PDH and 6PGDH } \\
\text { activities }\end{array}$ & $\begin{array}{l}\text { Alleviate pericarp } \\
\text { browning and aril } \\
\text { breakdown }\end{array}$ & $\begin{array}{l}\text { Chumyam et al. } \\
\text { (2016) } \\
\text { Lin et al. (2019a) }\end{array}$ \\
\hline $\begin{array}{l}\text { Broccoli flower } \\
\text { (Brassica oleracea var. Italica) }\end{array}$ & $\begin{array}{l}\text { Higher G6PDH and 6PGDH } \\
\text { activities }\end{array}$ & $\begin{array}{l}\text { Alleviate floret } \\
\text { yellowing }\end{array}$ & $\begin{array}{l}\text { Li et al. (2016, } \\
\text { 2017) }\end{array}$ \\
\hline $\begin{array}{l}\text { Mushroom } \\
\text { (Agaricus bisporus L.) }\end{array}$ & $\begin{array}{l}\text { Higher G6PDH and 6PGDH } \\
\text { activities }\end{array}$ & $\begin{array}{l}\text { Alleviate cap } \\
\text { browning }\end{array}$ & $\begin{array}{l}\text { Yang et al. (2019); } \\
\text { Li et al. (2019c) }\end{array}$ \\
\hline $\begin{array}{l}\text { Mushroom } \\
\text { (Flammulina velutipes) }\end{array}$ & Higher G6PDH activity & $\begin{array}{l}\text { Alleviate cap } \\
\text { browning }\end{array}$ & Yang et al. (2019) \\
\hline $\begin{array}{l}\text { Guava fruit } \\
(\text { Psidium guajava } \mathrm{L} .)\end{array}$ & $\begin{array}{l}\text { Higher G6PDH and 6PGDH } \\
\text { activities }\end{array}$ & $\begin{array}{l}\text { Alleviate } \\
\text { browning }\end{array}$ & $\begin{array}{l}\text { Chumyam et al. } \\
\text { (2019) }\end{array}$ \\
\hline $\begin{array}{l}\text { Nectarine fruit } \\
(\text { Prunus persica } \mathrm{L} .)\end{array}$ & $\begin{array}{l}\text { Higher G6PDH and 6PGDH } \\
\text { activities }\end{array}$ & $\begin{array}{l}\text { Alleviate pericarp } \\
\text { browning }\end{array}$ & Zhang et al. (2019) \\
\hline \multicolumn{4}{|l|}{ Fungal decay } \\
\hline $\begin{array}{l}\text { Longan fruit } \\
\text { (Dimocarpus longan L.) (pathogen: } \\
\text { Phomopsis longanae) }\end{array}$ & $\begin{array}{l}\text { Higher G6PDH and 6PGDH } \\
\text { activities }\end{array}$ & $\begin{array}{l}\text { Alleviate pericarp } \\
\text { browning }\end{array}$ & Chen et al. (2020) \\
\hline $\begin{array}{l}\text { Apple fruit } \\
\text { (Malus domestica L.) (pathogen: } \\
\text { Penicillium espansum) }\end{array}$ & Higher G6PDH activity & Attenuate decay & $\begin{array}{l}\text { Wei et al. (2019); } \\
\text { Li et al. (2020) }\end{array}$ \\
\hline $\begin{array}{l}\text { Grape berry fruit } \\
\text { (Vitis vinifera L.) (pathogen: Botrytis } \\
\text { cinerea) }\end{array}$ & $\begin{array}{l}\text { Higher G6PDH and 6PGDH } \\
\text { activities }\end{array}$ & Attenuate decay & Wang et al. (2019) \\
\hline
\end{tabular}


Table 4. NADPH content in fruits of different species under natural ripening or after 851 treatment with different compounds. BABA, $\beta$-aminobutyric acid. G6PDH, glucose-6852 phosphate dehydrogenase. GSH, glutathione. 6PGDH, 6PGDH, 6-phosphogluconate 853 dehydrogenase. MDA, malondialdehyde. PAL, phenylalanine ammonia lyase PPO, 854 polyphenol oxidase

\begin{tabular}{|c|c|c|c|c|c|}
\hline Fruit & Treatment & $\begin{array}{c}\text { NADPH } \\
\text { content }\end{array}$ & Biochemical effects & Effects & References \\
\hline $\begin{array}{l}\text { Longan } \\
\text { (Dimocarpus } \\
\text { longan L.) }\end{array}$ & $\begin{array}{c}\text { Chlorine } \\
\text { dioxide }\left(\mathrm{ClO}_{2}\right) \\
(10 \mathrm{mg} / \mathrm{L}) 10 \\
\text { min } \\
\text { fumigation } \\
\end{array}$ & Increase & $\begin{array}{l}\text { Higher G6PDH, 6PGDH, } \\
\text { MDAR, DHAR and GR } \\
\text { activities; AA/DHA and } \\
\text { GSH/GSSG ratio. } \\
\text { Lower } \mathrm{H}_{2} \mathrm{O}_{2} \text { accumulation }\end{array}$ & $\begin{array}{l}\text { Reduces } \\
\text { browning } \\
\text { and } \\
\text { disease }\end{array}$ & $\begin{array}{l}\text { Chumyam } \\
\text { et al., } \\
(2017)\end{array}$ \\
\hline $\begin{array}{l}\text { Guava } \\
\text { (Psidium } \\
\text { guajava L.) }\end{array}$ & $\begin{array}{c}\mathrm{H}_{2} \mathrm{O}_{2} \\
(250 \mathrm{mM}) \\
\text { for } 10 \mathrm{~min}\end{array}$ & Increase & $\begin{array}{l}\text { Higher G6PDH and 6PGDH } \\
\text { activities, GSH/GSSG ratio, } \\
\text { ascorbate, peroxiredoxin and } \\
\text { thioredoxin reductase activities. } \\
\text { Lower electrolyte leakage and } \\
\text { MDA content. Lower PPO } \\
\text { activity }\end{array}$ & $\begin{array}{l}\text { Reduces } \\
\text { browning }\end{array}$ & $\begin{array}{l}\text { Chumyam } \\
\text { et al., } \\
(2019)\end{array}$ \\
\hline $\begin{array}{l}\text { Grape berry } \\
\text { (Vitis vinifera } \\
\text { L.) }\end{array}$ & $\begin{array}{l}\text { BABA } \\
(10 \mathrm{mM})\end{array}$ & Increase & $\begin{array}{l}\text { Higher: G6PDH, 6PGDH, } \\
\text { MDAR, DHAR and GR } \\
\text { activaties; GSH/GSSG ratio; } \\
\text { endogenous SA and NO } \\
\text { accumulation, PAL and chitinase } \\
\text { genes expression }\end{array}$ & $\begin{array}{l}\text { Increases } \\
\text { resistance } \\
\text { Botrytis } \\
\text { cinerea } \\
\text { decay }\end{array}$ & $\begin{array}{l}\text { Wang et } \\
\text { al., (2019) }\end{array}$ \\
\hline $\begin{array}{l}\text { Peach } \\
\text { (Prunus } \\
\text { persica L.) }\end{array}$ & $\begin{array}{c}\text { BABA } \\
(10 \mathrm{mM})\end{array}$ & Increase & $\begin{array}{l}\text { Higher G6PDH and 6PGDH } \\
\text { activities; GSH and NO content; } \\
\text { and expression of pathogen } \\
\text { related genes (PpNPRI-like, } \\
\text { PpCHI and PpGNS) }\end{array}$ & $\begin{array}{l}\text { Increases } \\
\text { resistance } \\
\text { to } \\
\text { Rhizopus } \\
\text { stolonifer }\end{array}$ & $\begin{array}{l}\text { Chen et al., } \\
(2019)\end{array}$ \\
\hline $\begin{array}{l}\text { Pepper } \\
\text { (Capsicum } \\
\text { аппиит L.) }\end{array}$ & $\begin{array}{l}\text { Natural } \\
\text { ripening }\end{array}$ & Increase & $\begin{array}{l}\text { Higher: 6PGDH, NADP-ICDH } \\
\text { and NADP-ME activities }\end{array}$ & $\begin{array}{l}\text { Fruit } \\
\text { maturation }\end{array}$ & $\begin{array}{l}\text { Mateos et } \\
\text { al., (2009) }\end{array}$ \\
\hline
\end{tabular}

